\title{
EVALUATING SUBURBAN BROWNFIELD REDEVELOPMENT INCENTIVES
}

\author{
By \\ Graham Robert Wilson \\ Master of Arts, Political Science: Wilfrid Laurier, 2007 \\ Bachelor of Arts, Political Science: Laurentian University, 2005
}

An MRP

Presented to Ryerson University

In partial fulfillment of the

Requirements for the degree of

Master of Planning

In the Program of

Urban Development

Toronto, Ontario, Canada, 2016

(c) Graham Robert Wilson, 2016 


\section{EVALUATING SUBURBAN BROWNFIELD REDEVELOPMENT INCENTIVES}

\section{AUTHOR'S DECLARATION FOR ELECTRONIC SUBMISSION OF A MRP}

I hereby declare that I am the sole author of this MRP. This is a true copy of the MRP, including any required final revisions.

I authorize Ryerson University to lend this MRP to other institutions or individuals for the purpose of scholarly research.

I further authorize Ryerson University to reproduce this MRP by photocopying or by other means, in total or in part, at the request of other institutions or individuals for the purpose of scholarly research.

I understand that my MRP may be made electronically available to the public. 


\section{EVALUATING SUBURBAN BROWNFIELD REDEVELOPMENT INCENTIVES}

(c) Graham Robert Wilson, 2016

Master of Planning

In

Urban Development

Ryerson University

\section{ABSTRACT}

Suburban contaminated property (brownfield) redevelopment projects in peripheral or lower-density municipalities often do not have the same expected returns as urban brownfields in dense cities like Toronto, which are aided by high residential sale prices. A survey $(n=17)$ of stakeholders' opinions found that brownfield redevelopment costs and complexity had increased since changes to environmental and planning regulatory frameworks were made. Existing financial incentives for brownfield redevelopment were reviewed in selected Greater Toronto and Hamilton Area (GTHA) municipalities. A pro forma analysis of a hypothetical mid-rise residential construction scenario was developed to test the current incentives against current market conditions (condo sale prices) in these municipalities, which were often not sufficient to make a project feasible in areas of low condo sale prices. A combination of incentives was found to be effective, and was recommended to be implemented by the Town of Whitby, which has many brownfields but no financial incentives.

Key Words: suburban brownfields; financial incentives; pro forma analysis. 


\section{EVALUATING SUBURBAN BROWNFIELD REDEVELOPMENT INCENTIVES}

\section{Acknowledgements}

I would like to thank Dr. Christopher De Sousa for his time and guidance during the development of this paper, as well as for completing the prior research that made this work possible.

I would also like to thank Dr. Steven Webber for getting me interested in financial analysis, and opening my eyes to this way of looking at planning problems.

I would like to thank the participants in this research; your opinions and experience helped give this paper a solid base in the "real world" of brownfield redevelopment.

Finally, I want to thank my wife Mary, for encouraging me to go back to school and for her support, patience, and wise input during the past two years. 


\section{Table of Contents}

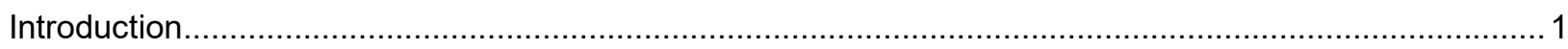

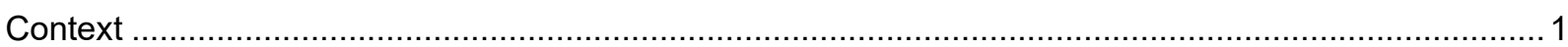

Scope

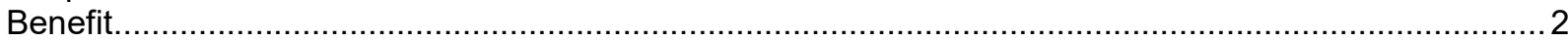

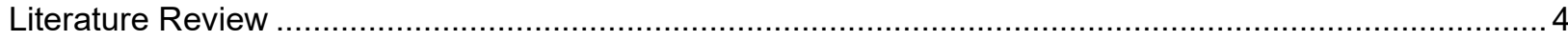

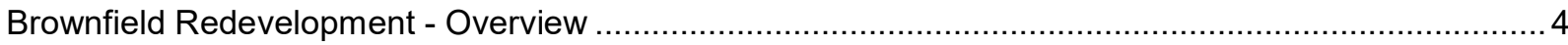

Brownfield Redevelopment and Financial Feasibility ................................................................ 4

Municipal Financial Incentives for Brownfield Redevelopment ................................................... 5

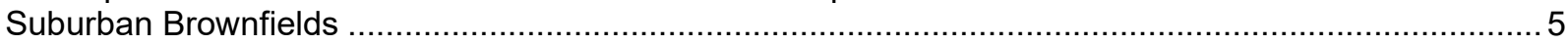

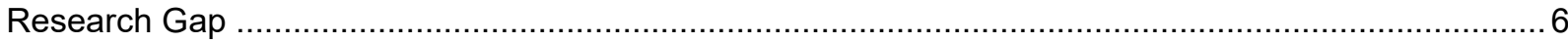

Methodology

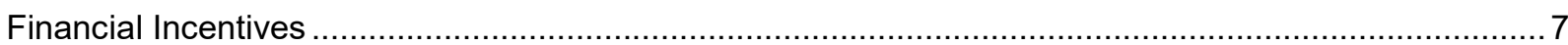

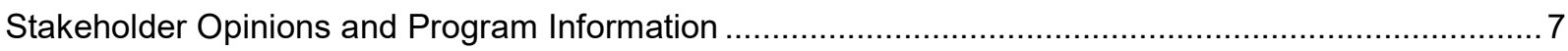

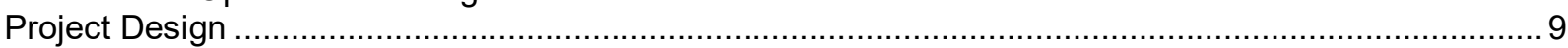

Market Factors .

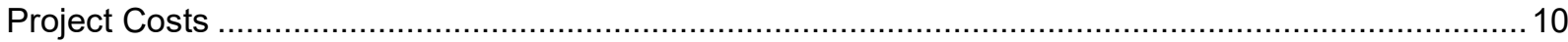

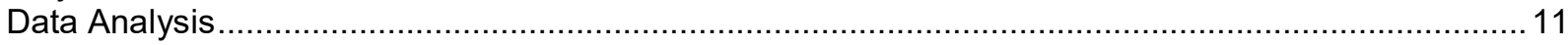

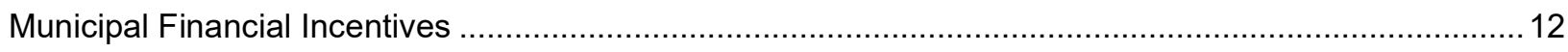

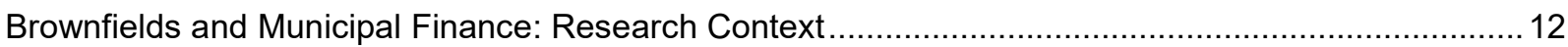

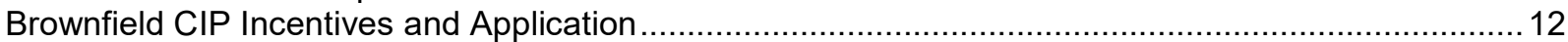

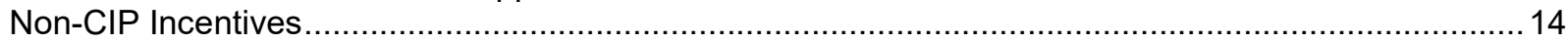

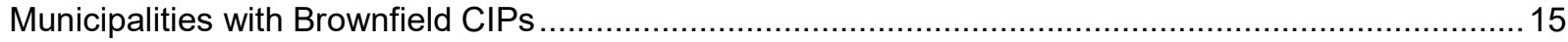

Municipal CIP Expenditures and Benefits - Windsor Case Study ................................................ 18

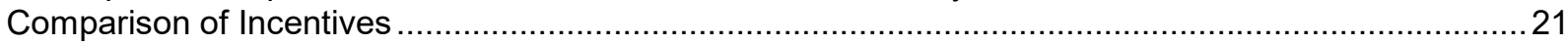

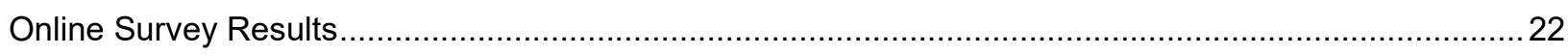

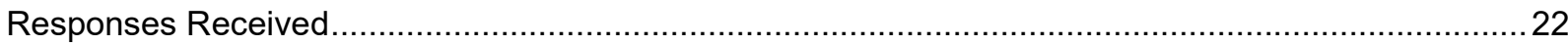

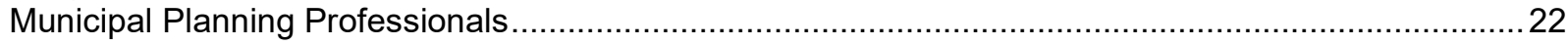

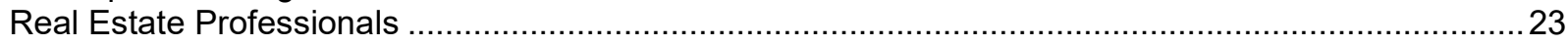

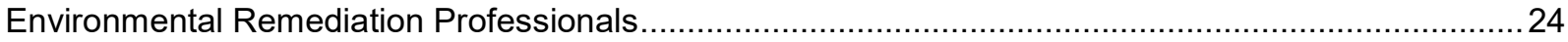

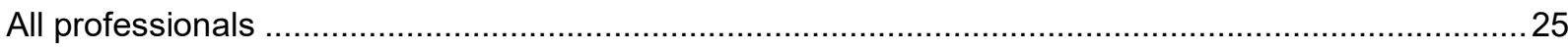

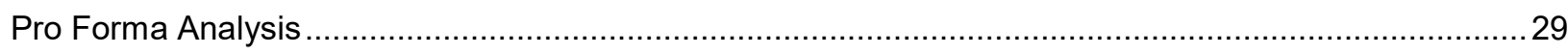

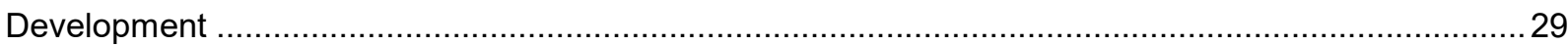

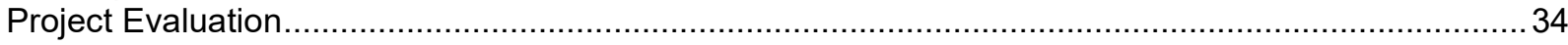

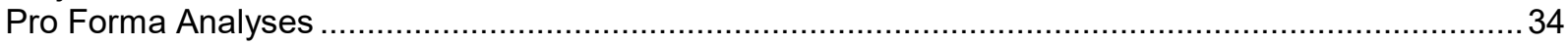

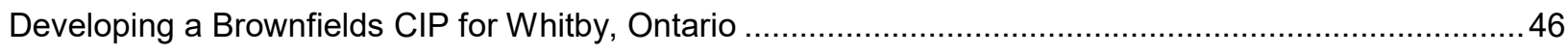

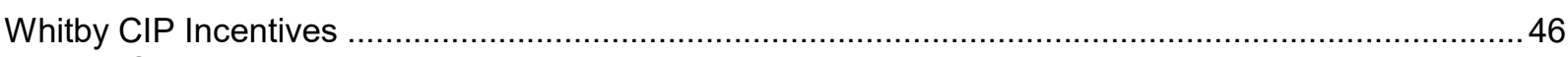

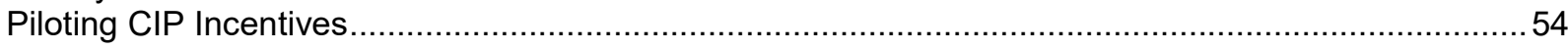

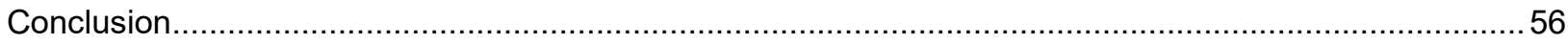

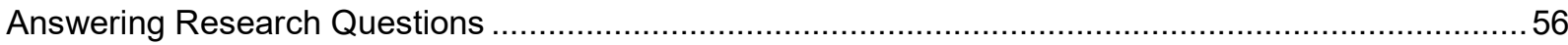

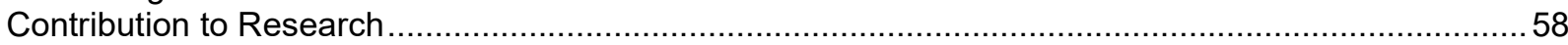

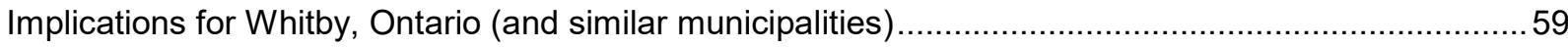

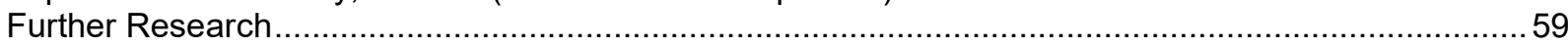

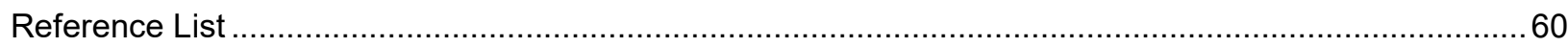




\section{List of Tables}

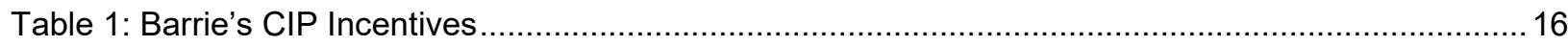

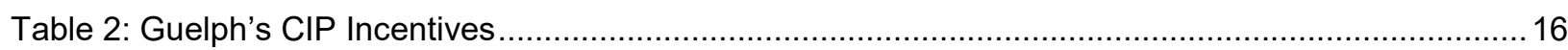

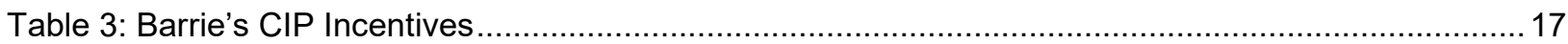

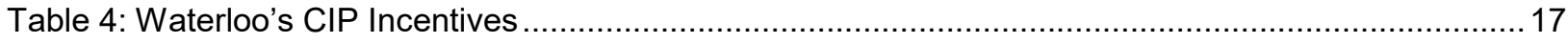

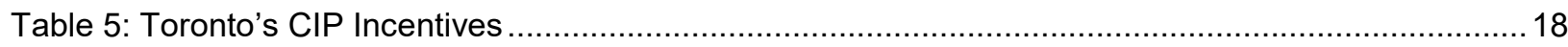

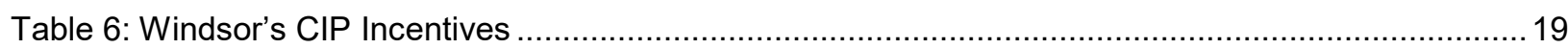

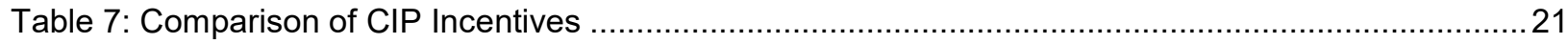

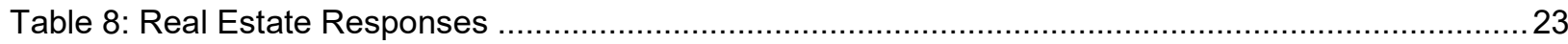

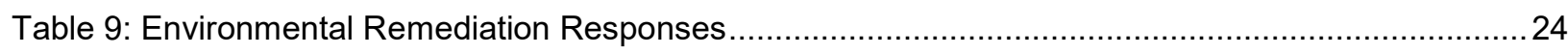

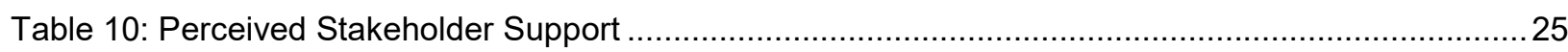

Table 11: Effects of changes to Record of Site Condition (RSC) regulations .....................................26

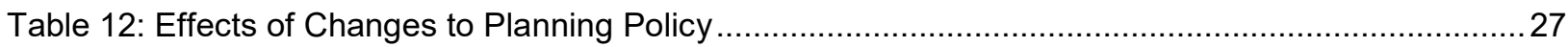

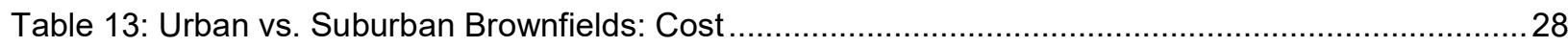

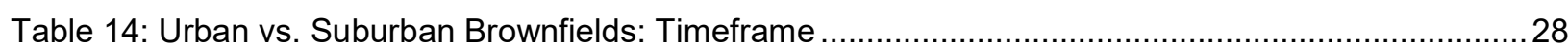

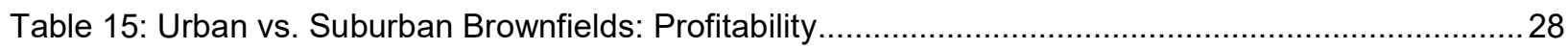

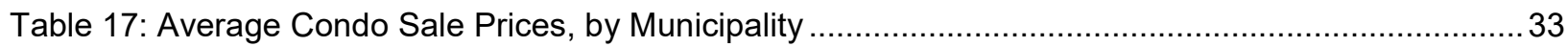

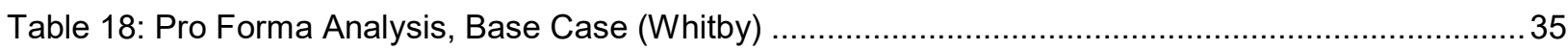

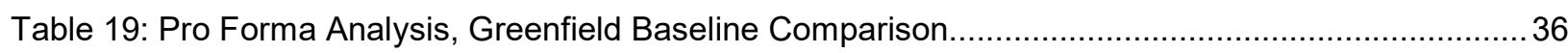

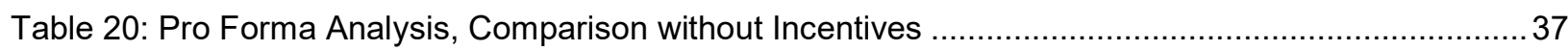

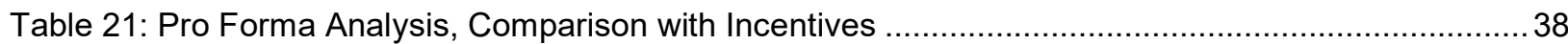

Table 22: Pro Forma Summary, Comparison with Bonus Density ...................................................... 40

Table 23: Pro Forma Summary, Comparison with Windsor's Incentives ..................................................4 41

Table 24: Pro Forma Summary, Sale Price of $\$ 1$ and Windsor's Incentives ..........................................4 43

Table 25: Pro Forma Summary, Comparison with Hybrid and Wooden Construction .............................44

Table 26: Summary of Recommended CIP Incentives for Whitby ......................................................49

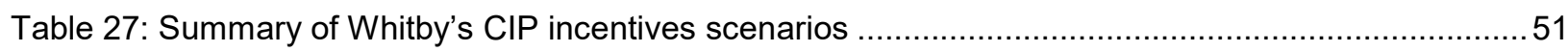

Table 28: Pro Forma Analysis, Alternate Construction, Comparison of Incentives ...................................52 


\section{List of Figures}

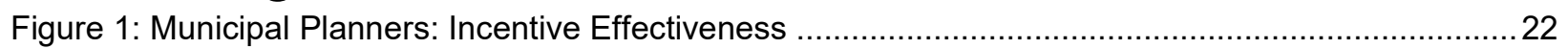

Figure 2: Real Estate Professionals: Incentive Effectiveness...........................................................24

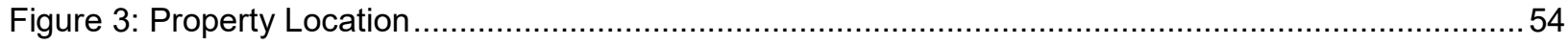

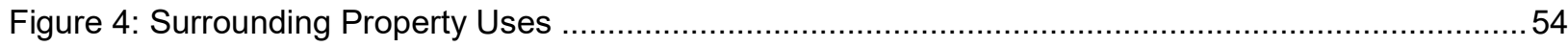

Figure 5: Street-level Panorama of 101 Victoria Street West and Adjacent Properties ..........................55 


\section{Introduction}

Changes in the Environmental and planning regulatory framework have made contaminated property (brownfield) redevelopment more desirable to municipalities, but also more complicated. While urban brownfield redevelopment projects (in dense cities like Toronto) are aided by high property values, suburban brownfields (in peripheral or lower-density municipalities) often do not have the same expected returns. Financial incentives are available for municipalities to encourage brownfield redevelopment, but they are not used uniformly in Ontario. This research attempted to answer the following questions:

1. Have stakeholders' impressions of the profitability (feasibility) of brownfield development changed in light of recent changes to the Environmental and planning regulatory framework?

2. Is brownfield development in Ontario suburbs financially feasible in comparison to Toronto, given lower market home prices?

3. Are existing financial incentives for brownfield redevelopment sufficient to close the feasibility gap and make suburban brownfield redevelopment financially feasible?

The first question was addressed through anonymous survey interviews of stakeholders from municipal planning staff, private developers, and environmental cleanup (remediation) professionals. Survey questions were focussed on their familiarity with brownfield redevelopment, and their opinions of its relative complexity and cost. The remaining questions were answered through a pro forma financial feasibility analysis of a hypothetical brownfield mixed-use redevelopment project in several suburban vs. urban settings, given current market conditions, and the financial incentives available in these areas.

\section{Context}

This analysis forms part of a larger body of research, looking at the financial feasibility of brownfield redevelopment in suburban municipalities in Ontario, with a focus on the Town of Whitby, in the Regional Municipality of Durham. The Town of Whitby is selected as a focus, as it has a heavy industrial history (as an active port in the 1800s) and no current brownfields community improvement plan or associated incentives.

Changes in the Environmental and planning regulatory framework have made brownfield redevelopment more desirable to municipalities, but also more complicated. Part of this complication is the split focus between the Province, which focuses on environmental impact and regulatory compliance; and municipalities, which see brownfield redevelopment as a primarily economic problem (Hayek et al, 2010).

While urban brownfield redevelopment projects are aided by high property values, suburban brownfields often do not have the same expected returns (De Sousa, 2006 \& 2009). Financial incentives are 
available for municipalities to encourage brownfield redevelopment, but they are not used uniformly in Ontario (MAH, 2012).

Much of my research to date has focussed on the financial incentives used in Community Improvement Plans (CIPs) for brownfields, and their effect on individual project feasibility (De Sousa, 2000, Hayek et al 2010). This included an analysis of a vacant former gas station at 101 Victoria Street West in Whitby1.

This paper is intended to bring this research together to form a comparison of current incentives used in different municipalities, and their effects on the feasibility of a similar hypothetical project located within each municipality.

\section{Scope}

This research project will look at brownfield redevelopment in suburban vs. urban areas in Ontario, from a developer's perspective of financial feasibility, market factors, and financial incentives for brownfield redevelopment.

This research looked at stakeholder impressions of challenges to suburban brownfield redevelopment in southern Ontario, the relative financial feasibility of suburban vs. urban brownfield redevelopments, and the estimated cost (through incentives) to municipalities to make such developments feasible.

- This research did not attempt to quantify the benefits of brownfield redevelopment through increased economic activity, environmental rehabilitation, or social benefits.

- This research did not attempt to look at exurban (i.e. outside of cities) brownfields.

- In addition, this research did not attempt to look at varying brownfield sizes, contaminants, or remedial methods; this research will use a hypothetical (but common) brownfield scenario: abandoned retail fuel outlets at arterial intersections, with an area of approximately 0.2 hectares.

\section{Benefit}

In order to understand the degree to which CIP incentives may be required in order to attract private investment in brownfield redevelopment, it is important to understand local market conditions, especially land values and housing costs. It is hoped that this research will provide additional tools to suburban municipalities in order to understand the real vs. imagined challenges and barriers facing brownfield redevelopment, and a better understanding of resources required in order to attract such development. It

1 This research was done for Professor Steven Webber's Urban Investments course. Based on an assumed $\$ 100 \mathrm{k}$ to $\$ 1 \mathrm{M}$ brownfield liability, the project (redevelopment of a 0.4 ha site into a high-rise condo/retail building based on an approved OPA designation for the site) would be financially unprofitable. Based on the pro forma analysis, Development Charge reductions or an aggressive Tax Increment Equivalent Grant would make the project feasible. 
is also hoped that this research will benefit suburban brownfield remediation by contributing to research on the applicability of remediation incentives, as well as by providing additional tools to municipalities to help guide the creation or adjustment of these incentives.

Pro Forma tools such as those used by De Sousa (2000) are useful in understand the feasibility gap of brownfield redevelopments in order to assess which incentives may make the project feasible with the least public cost. Some municipalities have demonstrated this concept through template or example pro formas in their CIPs (Belleville, 2011). It is hoped that the pro forma tool developed for this paper can be adopted or adapted by municipalities to help them understand how their local market conditions can be augmented with specific incentives to achieve Community Improvement Plan objectives; furthermore, having an understanding of the particulars of a development scenario can help municipalities to have a better bargaining position when it comes to negotiating incentives with the development community.

Finally, the aim of this research is to recommend financial incentives to be implemented as part of a brownfields CIP for the Town of Whitby, based on its market conditions and nearby CIP examples. This report will be forwarded to the Planning and Development department for information purposes, along with the pro forma tools created to evaluate brownfield properties to determine the necessary incentives. 


\section{Literature Review}

Much of the literature in this area deals with countries other than Canada. Where possible, Canadian sources were used, although only a limited number of studies were reviewed.

\section{Brownfield Redevelopment - Overview}

The benefits of brownfield redevelopment have been studied extensively elsewhere, and can include positive economic, social, and environmental outcomes. The now-defunct National Round Table on the Environment and the Economy (NRTEE) discussed these possible benefits (NRTEE, 1998), and advocated for a national strategy for redeveloping brownfields in Canada (NRTEE, 2003), and for focusing less on the public cost of remediation and more on the potential gain from redevelopment (NRTEE \& CBN, 2005). However, brownfield redevelopment is also seen as "necessary but not sufficient" for local economic growth (Howland, 2007), and requires government investment, which may or may not be recouped, depending on a variety of external factors such as real estate markets and economic trends (Metcalf et all, 2011).

Brownfield redevelopment is important to the planning practice as it requires different planning approaches than greenfield development; standard planning tools such as development charges and parkland dedication fees work differently for properties that have been previously developed and serviced (Koll-Schretzenmayr, 1999). The approaches to brownfield developments vary by different levels of government, with Provincial and Municipal government seeing the problem from different perspectives, with different implications (Hayek, 2010).

\section{Brownfield Redevelopment and Financial Feasibility}

De Sousa $(2000,2002,2006,2006 a, 2009)$ notes that much of the literature on brownfield redevelopment has focused on its technical aspects, and begins to fill this gap with studies of the private sector perspective on the costs and benefits of brownfield redevelopment. De Sousa (2000) used pro forma financial analysis to demonstrate the relative profitability of urban brownfield vs. greenfield test cases, to show that brownfield redevelopment can nonetheless be more profitable than greenfield development in certain circumstances. In general, the private sector perceives the costs and liabilities associated with brownfield redevelopment to be a barrier to development, although certain uses (primarily residential in Canada) are perceived as being profitable despite cleanup costs (De Sousa, 2000). The risk associated with the cleanup and long-term liability from brownfield redevelopment is not insignificant, and the inability to accurately model subsurface contaminant behaviour can amplify a project's liability (Yu et al, 2012). 


\section{Municipal Financial Incentives for Brownfield Redevelopment}

Although there are different views among Canadian municipalities regarding their role in dealing with brownfield redevelopment (De Sousa, 2006a), there are tools available to municipalities to reduce the financial risk associated with brownfield redevelopment. These tools, including Tax Incremental Financing and development charge reductions, are perceived as effective by the private sector in reducing the financial risk (De Sousa, 2000) associated with brownfield projects. Community Improvement Plans (CIPs) (s.28 of the Planning Act) have been used in Ontario since 1999, when Hamilton became the first municipality to implement them (De Sousa, 2006a). Currently, most incentives for brownfield development are a form of municipal funding through Provincial enabling legislation, whereas incentives in the US are often funded through the federal government (De Sousa, 2002). Public funding for brownfield redevelopment can be seen as more socially acceptable than other social funding for addressing urban decay, specifically in the US (Greenberg, 2003).

Opposing views contend that off-site investments like infrastructure and transportation may do more to attract redevelopment than direct investment in the brownfield, by solving underlying problems related to the market value of the property (Meyer \& Lyons, 2000). These investments may be integrated into brownfield redevelopment programs in order to approach the issue of feasibility from both sides (Amekudzi \& Fomunung, 2004).

Specific Incentives are discussed in more detail later in this paper.

\section{Suburban Brownfields}

Canadian municipalities in suburban areas generally give brownfields a lower priority than those in urban areas (De Sousa, 2006a). For the purpose of this research, suburban municipalities are defined as municipalities surrounding older central cities; Toronto is considered an urban municipality, with the surrounding Greater Toronto and Hamilton Area (GTHA) municipalities are considered suburban in relation to Toronto, by virtue of their smaller size, lower density, and the availability of greenfield land within the municipal boundaries. The feasibility of remediating suburban brownfields is negatively affected by two factors: increased availability of greenfield properties within city limits (ibid); as well as lower property values and demand (and therefore profitability) than urban areas (ibid). While CIPs can make suburban brownfield developments more attractive to the private sector, they do not negate market forces (Hayek et al, 2010), which make urban brownfields more attractive.

Financial incentives are available for municipalities to encourage brownfield redevelopment, but they are not used uniformly by municipalities in Ontario (MAH, 2012). Specific municipal incentive packages are discussed in more detail later in this paper. 


\section{Research Gap}

There has been a change in the brownfield regulatory process in Ontario since many of these reports were written, with the introduction and strengthening of the Record of Site Condition process $(\mathrm{O}$. Reg. 153/04 and O. Reg. 511/09, as amended). A Record of Site Condition is a certified statement of the environmental condition of a property, and is required by the Ministry of the Environment and Climate Change (MOECC) to allow a property to be redeveloped for a more sensitive use ${ }^{2}$. for example, an former industrial-use brownfield may not be used for residential purposes until a Record of Site Condition has filed with the MOECC.

The introduction of the Growth Plan for the Greater Golden Horseshoe has placed new pressures on suburban municipalities in the area to redirect development to infill areas. In addition, new financial incentives are available to municipalities to encourage brownfield redevelopment.

Given these changes, a significant research gap exists in the understanding the current regulatory and financial challenges for brownfield development, and the effectiveness of financial incentives in improving the financial feasibility of suburban brownfield redevelopment.

Furthermore, Ontario is currently in the process of reviewing four provincial land use plans, including the Growth Plan and the Greenbelt Plan (MAH, 2015b), which may have implications for the types and amounts of incentives available to municipalities. A government-created Advisory Council was formed to make recommendations on ways to amend and improve the plans. These recommendations included the improved use of incentives to achieve intensification targets (Crombie et al, 2015). It is important to understand which incentives are seen to be most effective, both in the opinion of stakeholders and by modelling their effects on project feasibility.

\footnotetext{
${ }^{2}$ Ontario Ministry of the Environment and Climate Change (2016). Brownfields Redevelopment. https://www.ontario.ca/page/brownfields-redevelopment
} 


\section{Methodology}

In order to answer the proposed research questions, a mixed-method approach of qualitative and quantitative data gathering was used (Neuman \& Robson, 2012). This consisted of the following:

1. Content analysis of available financial incentives for brownfield redevelopment;

2. Online surveys of stakeholder opinions and experience of brownfield redevelopment;

3. Review of market factors (construction costs and home pricing) in case study municipalities; and

4. A financial (pro forma) analysis of hypothetical brownfield and greenfield scenarios.

Based on the research questions asked, the existing literature, and the resources available to me, the most appropriate method for completing the research was determined to be a combination of survey interviews of stakeholder opinions with a mix of qualitative and quantitative questions (for the first research question, which seeks to understand stakeholder opinions), and a quantitative analysis of financial feasibility of a brownfield development and the effects of financial incentives (for the second and third questions, which are evaluative and quantitative in nature).

The research was conducted on stakeholders and data from a small number of southern Ontario municipalities with Community Improvement Programs and brownfield incentives, as indicated by MAH (2010) and independent research of publicly available documents and websites.

The following municipalities were selected: Barrie, Brantford, Guelph, Hamilton, Oshawa, Toronto, Waterloo, and Whitby. The City of Windsor was also selected as an example of an outside GTHA municipality with strong brownfield incentives. These municipalities were chosen to represent a variety of municipalities within or near the GTHA with diverse markets and brownfield incentives.

\section{Financial Incentives}

I used MMAH reports (Including MMAH 2010) and other information and publications available from provincial or municipal websites in order to determine the types and details of financial incentives available in the case study areas, and in Ontario in general. Information on these incentives was incorporated into the pro forma analysis.

\section{Stakeholder Opinions and Program Information}

Stakeholder opinions were gathered through survey interviews. The questions in the survey interview sought to identify their familiarity with brownfield development, their opinion of the effects of regulatory changes, and their opinion on the feasibility of suburban vs. urban brownfield redevelopment. The 
research method was reviewed and approved by the Ryerson Research Ethics Board on January 18, 2016 (REB 2015-387).

\section{Target Population}

Stakeholders surveyed were from municipal planning offices, real estate developers, and environmental professionals (designated Qualified Persons in Environmental Site Assessment or QPESA as per the MOECC). Stakeholders were selected from the following sources:

- The Ontario Ministry of the Environment and Climate Change registry of Records of Site Condition (RSCs) filed since July 1, 20113. All RSCs filed within the target municipalities were examined, in order to identify the developer and environmental professional involved (if available).

- Members of the Canadian Brownfields Network (CBN)

- A recruitment notice was posted on Facebook and Linkedln

\section{Sample Size and Selection}

The target sample size was approximately 10 respondents in each group (30 total), ideally with an approximate $60 \% / 40 \%$ split between respondents from suburban and urban areas. In all cases below, a combination of quota and snowball sampling was used to get a sufficient number of respondents which will have the appropriate experience (Neuman \& Robson, 2012).

Municipal planners were initially selected based on municipal staff directories on municipal websites.

Private developers and Environmental consultants were selected from publicly available records of site conditions (RSCs) filed since 2011, members of the Canadian Brownfields Network (CBN) as of November 23, 2015, open calls for participants posted on Facebook and Linkedln, and referrals from potential participants.

Potential participants were contacted initially by email, based on an approved script. In total, the following number of potential respondents were contacted:

- 82 Real Estate Development Professionals;

- 101 Environmental Professionals; and

- 27 Municipal Planners or Planning Departments

Potential participants were asked to indicate their interest in completing an anonymous survey, which was approved by Ryerson University's Research Ethics Board. Referrals and respondents to the open call for participants were invited to contact the researcher to indicate their interest. Interested participants were

${ }^{3}$ https://www.ontario.ca/environment-and-energy/records-site-condition 
then forwarded a link to the survey, which they were free to view, complete, or refuse without my knowledge. The following completed survey responses were received (based on self-identified professions):

- 4 responses from Real Estate Development Professionals;

- 13 responses from Environmental professionals; and

- 1 response from Municipal Planning professionals

This is short of my initial goal, but still represents valuable data on industry opinions, especially those of environmental professionals.

\section{Survey Instrument}

Stakeholders were given a short survey interview (less than 20 questions) in order to get their opinions of brownfield redevelopment. As indicated above, the survey was based heavily on De Sousa's survey research (2000), with a limited number of questions and additions for the suburban context.

The survey questions were specific in nature, with very few open-ended questions. Most questions were in the form of yes or no answers, estimates of cost, and Likert-scale type ordinal questions. A copy of the survey instrument is included in Appendix A.

\section{Survey Completion Method and storage}

The survey was stored on Ryerson's Google Drive service, and links were sent out by email appended to participant consent forms. Responses were stored on Ryerson's Google Drive service, with access restricted to myself and Dr. De Sousa. All survey responses were anonymous.

\section{Project Design}

The pro forma portion of this research was based on a development scenario of a 0.2 ha property, formerly a retail fuel outlet, being redeveloped as a residential condo apartment building with $100 \%$ lot coverage and 4 storeys tall. This was considered an appropriate development scenario, based on similar developments being currently developed and sold in the target municipalities.

\section{Market Factors}

It is necessary to understand the likely revenue that a redevelopment project would make, and how this varies among the case study locations. The primary measure of project revenue was average condominium sale prices. This involved limited primary research as well as relying on established 
secondary data, as the results of the pro forma analysis are greatly affected by the accuracy of these values.

\section{Primary Data - online research}

I used freely available online sources such as BuzzBuzzHome (www.buzzbuzzhome.com) in order to determine the market rate for condo apartments in the case study areas. I viewed available postings to identify the market for condo developments of approximately 4 stories or greater in study areas. Where such developments were absent (i.e. Oshawa and Brantford), the proposed development was considered not practical and these study areas were dropped. The average condo sale values for each of the remaining study areas was used to calculate the sale revenues of the project.

\section{Secondary Data - Market analyses}

I used freely available online analytical reports, such as those available from Colliers Canada, CBRE, and N. Barry Lyon Consultants Limited. These reports contain information on commercial and residential market trends in Ontario, including rental and condominium sale prices. I used the most recent reports, where available, and selected the appropriate values for use in the pro forma.

\section{Project Costs}

It is necessary to have an accurate understanding of the costs of the proposed development (including "hard costs", "soft costs", financing costs, remediation costs) in order to accurately determine its feasibility. This information was obtained from both primary and secondary sources, with examples shown below

\section{Primary Data - Municipal bylaws}

I used municipal by-laws to determine development charges, parking requirements, and other fees associated with the proposed redevelopment in each of the case study areas.

\section{Secondary Data - construction reports}

I used freely available online sources such as Altus Group's Construction Cost Guides, available at www.altusgroup.com. These reports contain industry averages for the construction costs of a variety of building types, which were incorporated into the pro forma analysis. 


\section{Data Analysis}

Data from the survey portion of the research was analysed using simple descriptive statistics, as no correlation or causal link was sought. Where sufficient data was available, responses from "urban" municipalities (i.e.: Toronto) was compared to responses from "suburban" municipalities (i.e.: All other municipalities).

Market, project cost, and incentive data will be compared using a pro forma analysis spreadsheet, which I designed. The feasibility of the projects will be judged based on their ROE (for static analysis, i.e.: build and sell) and/or IRR (for longitudinal analysis, i.e. build and hold) as judged against the target of $15 \%$. The cost to municipalities will be evaluated by determining the reduction in project costs necessary to make the ROE/IRR reach $15 \%$. 


\section{Municipal Financial Incentives}

This section covers brownfield redevelopment incentives for suburban redevelopments. A brief summary is made of incentives available to municipalities in Ontario, generally under s.28 of the Planning Act. Community Improvement Plans (CIPs) of selected municipalities (by availability) are then reviewed and incentives identified. The city of Windsor is considered as an outside example, because of its interesting incentives and available budget information.

This review includes the Town of Whitby, which has an industrial past and no current brownfield redevelopment incentives, but is in the process of updating its secondary plan for an area with many brownfields, including developing a CIP with brownfield incentives.

\section{Brownfields and Municipal Finance: Research Context}

This study first briefly identified incentives available to municipalities under s.28 of the Planning Act. CIPs of selected municipalities (by availability) were then reviewed and incentives identified, with accompanying budgets where available.

\section{Brownfield CIP Incentives and Application}

Most incentives for brownfield development are a form of municipal funding through Provincial enabling legislation. This is unlike incentives in the US, which are often funded through the federal government (De Sousa, 2002), even though federal bodies like the former National Round Table on the Environment and the Economy (NRTEE) have recommended a national framework for financial incentives for brownfield redevelopment (NRTEE, 2003 \& 2005). This results in Canadian municipalities bearing a higher financial burden for brownfield redevelopment relative to their US counterparts.

Ordinarily, s. 106 of the Municipal Act prohibits municipalities from granting bonuses in order to assist industrial or commercial enterprises; this includes grants, lending, discounting, or fee exemption. However, s.106(3) allows exceptions for supporting developments which achieve municipal objectives under s. 28 of the Planning Act, or s.365.1 of the Municipal Act.

The legal basis for financial incentives is primarily under Part IV of the Planning Act, "Community Improvement" (s. 28). This sets out the types of incentives can be granted, and the procedure of their implementation: the municipality must declare a Community Improvement Project Area in their Official Plan, and then develop a Community Improvement Program/Plan (CIP) which contains specifics about the incentives to be made available. 
Generally, incentives available under s. 28 of the Planning Act include grants or loans to pay for eligible costs defined under the CIP, which are set out in the Planning Act. For the purposes of brownfield redevelopment, eligible costs include Environmental Site Assessment (ESA) studies, remediation activities, and associated works.

\section{Environmental Site Assessment (ESA) Study Grants}

ESA Study Grants are grants applied against a portion of the cost of conducting ESAs and other environmental studies at the property. These are generally required under O.Reg.153/04 of the Environmental Protection Act when changing the use of a property to a more sensitive use, or when redeveloping on a property with a previous potentially contaminating activity. ESAs can range in expense from under $\$ 10,000$ to over $\$ 100,000$, depending on the complexity of the property 4 .

Study grants are generally payable after the completion of the study. For the purpose of this paper, this is assumed to be during the first year of development, as an offset to "soft costs".

\section{Tax Assistance Program (TAP) and Brownfield Financial Tax Incentive Program (BFTIP)}

s. 365.1 of the Municipal Act allows municipalities with CIPs to include tax cancellation for all or a portion of municipal and school taxes on eligible properties, based on conditions set in the CIP. Provincial approval is needed for the school portion of these taxes. The TAP refers to the cancellation of the municipal portion of the property taxes. The BFTIP refers to the cancellation of the school portion of municipal property taxes, with Provincial approval (MAH, 2012). The time limit for BFTIP is currently 3 years. TAP may also be referred to as Tax Assistance, or Brownfield Remediation Tax Assistance (BRTA) in Toronto.

\section{Tax Increment Equivalent Grant (TIEG)}

TIEGs are sometimes confused with Tax Increment Financing (TIFs). TIFs are generally used by municipalities to fund capital budget items or infrastructure spending by leveraging projected increases in municipal tax in the benefiting areas (Weber, R. 2007). This confusion is increased by the Ministry of Municipal Affairs and Housing (MAH) describing the function of TIEGs in a webpage titled "Tax Increment-Based Financing" (MAH, 2015).

TIEGs are generally paid to the property owner after the rehabilitation of a property (remediation and construction). The grant is based on a percentage of the Tax Increment, which is the post-rehabilitation

4 Based on previous professional experience conducting and coordinating ESAs for real estate management companies on a variety of property sizes and contaminants of concern. 
increase in the property taxes levied against a property. The property taxes are paid by the proponent as normal, who then receives a grant from the municipality which is equivalent to the tax increment. This grant can therefore be seen as somewhat revenue-neutral, as it is a repayment of the property tax on the increase in value of a property, which would not have been payable had the property not been rehabilitated.

\section{Non-CIP Incentives}

Some incentives are commonly used which do not technically fall under CIP provisions, but which achieve the same goals and are therefore commonly included in CIPs for ease of use.

\section{Development Charge Reductions}

Section 5(1).10 of the Development Charges Act allows for full or partial exemptions of development charges on specific types of development. This can be included into CIPs in order to offer Development Charge reductions for desired developments.

\section{Brownfield Inventory}

Part of the difficulty with quantifying the need for incentives is lack of certainty on the number of properties requiring remediation. Property owners are often unwilling for legal reasons to share sensitive environmental information about their property, which may reduce its sale value through added liability. One non-financial tool a municipality can create is an inventory of brownfields, based on publicly available records of past property use. This can be an internal tool used by city staff to estimate the number of properties requiring remediation, and to target incentives to those properties which are of the highest importance or have the most suspected contamination. Inventories are not uniformly used in Canada (De Sousa, 2006).

\section{Parking Requirement Reductions}

Parking can be a significant cost of high density developments, especially parking structures or underground parking (Altus Group, 2015). One way to reduce development costs without incurring direct public costs can be the reduction of parking requirements, where appropriate. This can be appropriate for transit oriented development (TOD) areas, where there is a higher likelihood that current and future tenants or customers may not need as many personal vehicles. Such incentives could be implemented through site-specific zoning exceptions. Parking requirement reductions were generally not considered for this project, because of the highly location-specific nature of the incentive, and the need to demonstrate lower traffic demand for the project; however, they should nonetheless be considered to be a very valuable incentive, and worth considering by municipalities. 


\section{Other Incentives}

Other incentives exist which are not detailed in this study. Of note is the Green Municipal Fund administered by the Federation of Canadian Municipalities (FCM), which offers separate grants and loans (FCM, 2014). These grants can be used by municipalities to develop sustainability plans or community improvement plans. These incentives were not considered in this study, as they were not directly related to the financial performance of a project.

\section{Municipalities with Brownfield CIPs}

As of 2010, 44 municipalities in Ontario had CIPs with brownfield provisions (MAH, 2010). This study looked at Brownfield CIPs in Barrie, Guelph, Hamilton, Waterloo, Whitby, and Toronto. These municipalities were chosen based on availability of CIPs with similar incentives, and their geographic location within approximately $100 \mathrm{~km}$ of Toronto. The City of Windsor was also selected as an example of an outside GTHA municipality with strong brownfield incentives.

As CIPs are not standardized, different municipalities have tailored CIPs to their perceived needs and resources available. A summary of CIP incentives is shown and compared in Table 1, at the end of this section. Selected information about each of the CIPs is discussed below.

\section{Barrie (2004)}

Barrie has 3 CIP Areas; the Downtown Barrie CIP was reviewed (City of Barrie, 2004). This CIP is not for Brownfield redevelopments, although Planning Staff Report PLN010-11 (May 2, 2011) ${ }^{5}$ recommended investigating the opportunity for CIP financial incentives for brownfield redevelopment in 2 of its 3 CIPs. Barrie's current CIP incentives are therefore included for illustrative purposes, in order to demonstrate the benefit of applying existing incentives to brownfield developments.

5 http://www.barrie.ca/Doing\%20Business/PlanningandDevelopment/Documents/Brownfields Staff Report May2 2011.pdf 
Table 1: Barrie's CIP Incentives

\begin{tabular}{|l|l|l|}
\hline Incentive & Planning Fee Grant & TIEG \\
\hline Amount & $\begin{array}{l}\text { 100\% of costs for ZBLAs, OPAs, } \\
\text { Site Plan Agreements }\end{array}$ & $\begin{array}{l}\text { 100\% of Tax Increment } \\
\text { Decreasing by 25\% per year } \\
\text { after Year 2 }\end{array}$ \\
\hline Duration & At beginning of development & $\begin{array}{l}\text { Yearly, after development and } \\
\text { reassessment }\end{array}$ \\
\hline Time released &
\end{tabular}

One interesting aspect of Barrie's CIP is the identification of priority properties for redevelopment. While there does not seems to be additional incentives for these specific properties, this idea could be carried forward to other CIPs.

\section{Guelph (2012)}

Guelph's Brownfield Redevelopment Community Improvement Plan (2012) includes Environmental Study Grants, TAP/BFTIP tax cancellation, and TIEGs. Of note, Guelph's TIEG is for $80 \%$ of the tax increment, while the remaining $20 \%$ is retained by the city.

Table 2: Guelph's CIP Incentives

\begin{tabular}{|l|l|l|l|}
\hline Incentive & ESA Study Grant & TAP / BFTIP & TIEG \\
\hline Amount & $\begin{array}{l}50 \% \text { of costs } \\
\text { Max } \$ 30,000\end{array}$ & $100 \%$ & $80 \%$ of Tax Increment \\
\hline Duration & At completion of Study & $\begin{array}{l}\text { during development } \\
\text { period }\end{array}$ & $\begin{array}{l}\text { Yearly, after } \\
\text { development and } \\
\text { reassessment }\end{array}$ \\
\hline Time released & & & up to 10 years \\
\hline
\end{tabular}




\section{Hamilton (2010)}

Hamilton's CIP (2014) is very detailed, and includes up-front "bridge" loans for up to $80 \%$ of remediation costs. This is one of the first Brownfield CIPs in Ontario.

Table 3: Barrie's CIP Incentives

\begin{tabular}{|l|l|l|l|}
\hline Incentive & ESA Study Grant & TAP / BFTIP & TIEG \\
\hline Amount & $\begin{array}{l}50 \% \text { of costs } \\
\text { Max \$25,000 }\end{array}$ & $100 \%$ & $80 \%$ of Tax Increment \\
\hline Duration & & up to 3 years & up to 10 years \\
\hline Time released & At completion of Study & $\begin{array}{l}\text { during development } \\
\text { period }\end{array}$ & $\begin{array}{l}\text { Yearly, after } \\
\text { development and } \\
\text { reassessment }\end{array}$ \\
\hline
\end{tabular}

\section{Waterloo (2013)}

The City of Waterloo's Brownfields Community Improvement Plan (2013) has a joint TIEG with the Region of Waterloo. This allows for a greater incentive in lower-tier municipalities.

Table 4: Waterloo's CIP Incentives

\begin{tabular}{|l|l|}
\hline Incentive & TIEG \\
\hline Amount & $\begin{array}{l}\text { up to 100\% of Tax Increment } \\
\text { (Municipal + Regional) }\end{array}$ \\
\hline Duration & up to 10 years \\
\hline Time released & $\begin{array}{l}\text { Yearly, after development and } \\
\text { reassessment }\end{array}$ \\
\hline
\end{tabular}

\section{Whitby (2004)}

The Town of Whitby's Community Improvement Plan (2004) does not apply to brownfields, and is limited to building permit grants and facade grants for the downtown area. It is noted that Whitby is currently drafting a Community Improvement Plan for the Port Whitby Secondary Plan Area, with early drafts including a TAP, TIEG, and Development Charge reduction. 


\section{Toronto (2012)}

Toronto's CIP (2012) is fairly restrictive, which is understandable given its high land value. TAP and TIEG incentives are only available for certain property uses.

Table 5: Toronto's CIP Incentives

\begin{tabular}{|l|l|l|}
\hline Incentive & TAP / BFTIP & TIEG \\
\hline Amount & $100 \%$ & $\begin{array}{l}100 \% \text { of Tax Increment, less } \\
\text { approximately 9\% per year }\end{array}$ \\
\hline Duration & up to 3 years & up to 10 years \\
\hline Time released & during development period & $\begin{array}{l}\text { Yearly, after development and } \\
\text { reassessment }\end{array}$ \\
\hline
\end{tabular}

\section{Municipal CIP Expenditures and Benefits - Windsor Case Study}

The City of Windsor's Brownfield Redevelopment CIP (2015) has several incentives that make it different from the municipalities considered.

Windsor offers funding for studies on the feasibility of rehabilitating brownfields (i.e. through the use of pro forma tools or similar methods), for $50 \%$ of the study up to a maximum of $\$ 7,500$ per property. This is different from ESA Study Grants, which require property access and intrusive sampling of soil and groundwater.

Windsor also offers an Environmental Study Grant up to $\$ 25,000$, a TAP / BFTIP, a TIEG for $70 \%$ (100\% with LEED certification), and a 60\% DC Exemption. 
Table 6: Windsor's CIP Incentives

\begin{tabular}{|c|c|c|c|c|c|}
\hline Incentive & $\begin{array}{l}\text { Feasibility } \\
\text { Study Grant }\end{array}$ & $\begin{array}{l}\text { ESA Study } \\
\text { Grant }\end{array}$ & TAP / BFTIP & TIEG & $\begin{array}{l}\text { DC } \\
\text { Exemption }\end{array}$ \\
\hline Amount & $\begin{array}{l}50 \% \text { of costs } \\
\operatorname{Max} \$ 7,500\end{array}$ & $\begin{array}{l}50 \% \text { of costs } \\
\text { Max } \$ 25,000\end{array}$ & $100 \%$ & $\begin{array}{l}70 \% \text { of Tax } \\
\text { Increment } \\
\text { (100\% with } \\
\text { LEED) }\end{array}$ & $60 \%$ of $\mathrm{DC}$ \\
\hline Duration & & & up to 3 years & up to 10 years & \\
\hline $\begin{array}{l}\text { Time } \\
\text { released }\end{array}$ & $\begin{array}{l}\text { At completion of } \\
\text { Study }\end{array}$ & $\begin{array}{l}\text { At completion of } \\
\text { Study }\end{array}$ & $\begin{array}{l}\text { during } \\
\text { development } \\
\text { period }\end{array}$ & $\begin{array}{l}\text { Yearly, after } \\
\text { development } \\
\text { and } \\
\text { reassessment }\end{array}$ & \\
\hline
\end{tabular}

Importantly, eligible expenses may be recouped twice in Windsor. For projects that achieve certain goals, including Smart Growth principles, the eligible costs recouped on Development Charge exemptions will not be deducted from grants payable through TAP/TIEG incentives. This means that brownfield developments may be more profitable than greenfield developments. While this may seem at first to run afoul with the Planning Act sections on maximum amounts: "The total of the grants and loans made ... shall not exceed the eligible cost" (s. 28(7.3)), this may be interpreted as an expansion of the definition of eligible costs, which may also include costs related to "development, redevelopment, construction, and reconstruction of lands and buildings for rehabilitation purposes" (s. 28 (7.1)). Therefore, this should be seen as a conforming use of CIP incentives.

\section{Expenditures}

The City of Windsor published an update on CIP spending in 2014-2015 (Windsor, 2015a), which includes brownfield redevelopment and economic revitalization incentives. Highlights of the report are detailed below:

- Windsor CIP incentives "have collectively leveraged nearly eight dollars of private sector investment for every public dollar of financial incentive approved." (Windsor, 2015a, p. 5)

- Windsor has paid out $\$ 3,594,833$ in financial incentives to date under these CIPs

- A total of $\$ 11,830,890$ in approved incentives will be paid out over the next 10-12 years.

- These incentives are generally in the form of credits on property tax increases, which would not have increased if the projects had not been completed.

- After incentives are paid out, Windsor will collect an additional $\$ 1,171,168$ annually in increased municipal tax revenue. 
- This does not include increases in tax revenue from adjacent or neighbouring properties that benefited from redevelopment in their locale.

- In the reporting period, one study grant was approved for $\$ 15,000$ towards a Phase II ESA on a former gas station at 775 Riverside Drive, which had been vacant since approximately 1990 . The property is zoned to permit multi-unit residential uses.

- In the reporting period, construction of a three-tenant commercial building on former vacant gas station at Dougall Avenue and West Grand Boulevard was completed. The project was approved for TIEG funding, and increased the assessed value of the property by $\$ 207,040$. The annual TIEG for the property is estimated at $\$ 9,019$, as calculated below:

- Based on a 2015 assessed value of $\$ 367,040^{6}$ and total 2015 taxes of $\$ 22,841.43$, the tax rate is estimated to be $6.22 \%$.

- The taxes on the increased assessment value is therefore estimated to be $\$ 12,884.40$ (tax increment).

- The TIEG for the property is therefore estimated at $70 \%$ of the tax increment, or $\$ 9,019$.

The City of Windsor is a good example of a city which uses CIPs to offset lower property values, and of a city with publicly accessible monitoring and publishing of CIP expenditures.

Of special importance for this study is that Windsor provides a stand-alone grant for feasibility studies for brownfield properties. This allows for early studies of brownfield properties to determine the sensitivity of the development to liabilities associated with environmental contamination before needing to obtain the proper permissions and contractors to determine the level of contaminant impact at the site.

${ }^{6}$ Information retrieved from the City of Windsor's Tax and Assessment Website, using the address of 3001 Dougall Ave, as retrieved from Google Maps based on street view imagery matching pictures from the Windsor 2014-2015 CIP update.

https://apps.citywindsor.ca/eservices/TaxesAndAssessment.aspx?Stream=TaxAssessment\&PropertyRS $\mathrm{N}=100980$ 


\section{Comparison of Incentives}

Based on the available information, information about incentives available in the different target municipalities was compared, in order to be added into the pro forma analysis. The City of Windsor's incentives are shown for illustrative purposes only.

Table 7: Comparison of CIP Incentives

\begin{tabular}{|c|c|c|c|c|c|c|c|}
\hline Municipality & Barrie & Guelph & Hamilton & Waterloo & Whitby & Toronto & Windsor \\
\hline $\begin{array}{l}\text { Priority } \\
\text { Sites }\end{array}$ & Yes & & & & & & \\
\hline $\begin{array}{l}\text { Feasibility } \\
\text { Study Grant }\end{array}$ & & & & & & & $\begin{array}{l}50 \% \\
\$ 7.5 \mathrm{k}\end{array}$ \\
\hline $\begin{array}{l}\text { ESA Study } \\
\text { Grant }\end{array}$ & & $\begin{array}{l}50 \%, \\
\$ 30 k\end{array}$ & $\begin{array}{l}50 \% \\
\$ 25 k\end{array}$ & & & & $\begin{array}{l}50 \% \\
\$ 25 \mathrm{k}\end{array}$ \\
\hline $\begin{array}{l}\text { DC } \\
\text { Exemptions }\end{array}$ & & & & & & & $\begin{array}{l}60 \% \\
\text { Does not } \\
\text { reduce } \\
\text { TAP/TIEG }\end{array}$ \\
\hline $\begin{array}{l}\text { Planning } \\
\text { Fee } \\
\text { Exemptions }\end{array}$ & $\begin{array}{l}100 \% \text { for } \\
\text { ZBLAs, } \\
\text { OPAs, Site } \\
\text { Plan }\end{array}$ & & & & & & \\
\hline TAP/BFTIP & & Yes & Yes & & & Yes & Yes \\
\hline TIEG & $\begin{array}{l}5 \text { Years } \\
\text { 1\&2: } 100 \% \\
\text { 3: } 75 \% \\
\text { 4: } 50 \% \\
5: 25 \%\end{array}$ & $\begin{array}{l}10 \text { Years } \\
80 \%\end{array}$ & $\begin{array}{l}10 \text { Years } \\
80 \%\end{array}$ & $\begin{array}{l}10 \text { Years } \\
100 \% \\
\text { Regional + } \\
\text { Municipal } \\
\text { Increment }\end{array}$ & & $\begin{array}{l}10 \text { Years } \\
100 \%, \\
\text { less } \\
9 \% / y r .\end{array}$ & $\begin{array}{l}10 \text { Years } \\
70 \%(+30 \% \\
\text { for LEED) }\end{array}$ \\
\hline
\end{tabular}

Note: The above is based on information available in each municipality's respective CIP on the date accessed. Some municipalities allow for specific incentives to be adjusted or removed without requiring an update of their CIP, or may have additional incentives not listed.

As shown above, the CIPs reviewed have different levels and types of incentives available. TIEGs were the only incentive that were included in all CIPs reviewed (with the exception of Whitby). For the purpose of recommending incentives for Whitby, the amount of incentives was generally chosen from the middle range of incentives found.

The following incentives were used in developing the pro forma: ESA Study Grants; Planning Fee Exemptions; TAP/BFTIP; and TIEG. DC Exemptions were also used for illustrative purposes, based off Windsor's example. 


\section{Online Survey Results}

This section summarizes the results of survey submissions. A brief analysis of survey results is made and carried forward to the development of the pro forma analysis.

\section{Responses Received}

Responses were received from:

- 13 Environmental Assessment / Remediation professionals;

- 4 Real Estate Development professionals; and

- 1 Municipal Planning professional.

This is based on self-reporting of profession; all responses were anonymous.

Years of experience among responses ranged from 8 to 45, with a median experience of 22 years.

Four of the respondents reported their primary work location as Toronto, while 10 respondents reported working in the GTHA.

\section{Municipal Planning Professionals}

As stated, only one Municipal Planning professional responded to the online survey. Below is the respondent's opinion on the effectiveness of various brownfield development incentives:

\section{Figure 1: Municipal Planners: Incentive Effectiveness}

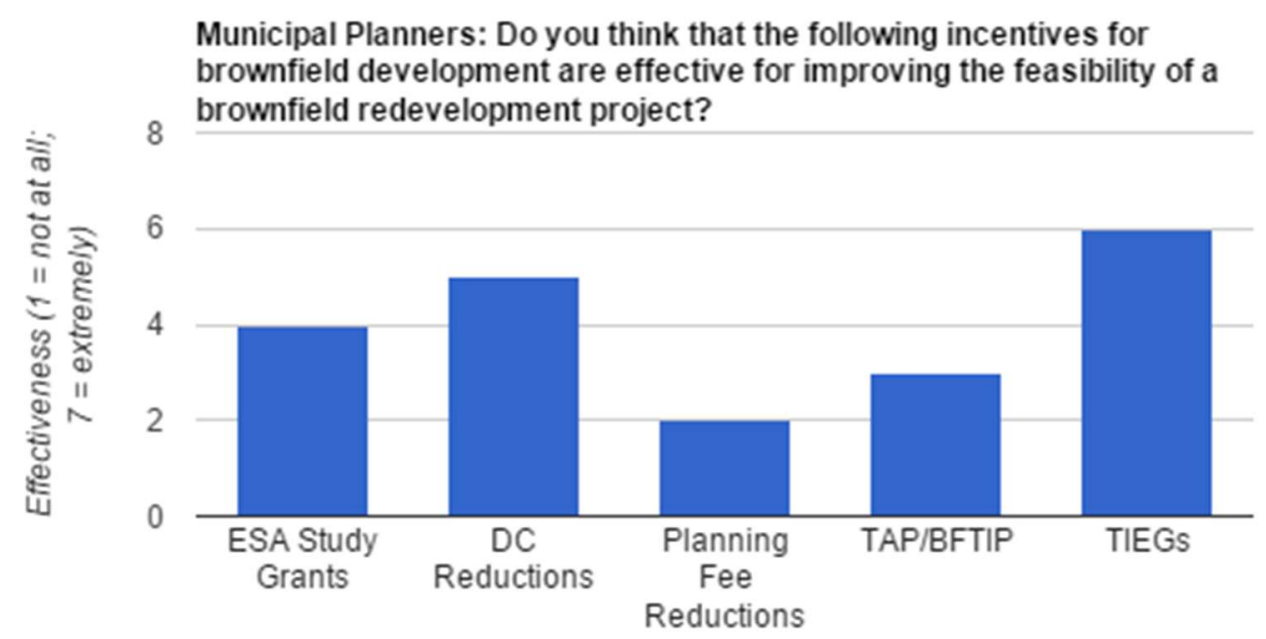

As shown, TIEGs were seen to be the most effective, followed by DC Reductions. Planning fee reductions were considered the least effective. 
Some of their remaining responses were not included in this report, in order to prevent them (or their municipality) from being identified. Where appropriate, their responses were aggregated with other responses and summarized (see All Professional section, below).

\section{Real Estate Professionals}

The responses from the 4 Real Estate Professional respondents are summarized below:

Table 8: Real Estate Responses

\begin{tabular}{|c|c|}
\hline Question & Response \\
\hline Where do you work? (aggregated) & $\begin{array}{l}\text { Toronto ( } 2 \text { responses) } \\
\text { GTHA ( } 1 \text { response) }\end{array}$ \\
\hline $\begin{array}{l}\text { Brownfield redevelopment projects completed in the last } 5 \\
\text { years within your company: }\end{array}$ & 2 to 20 (average: 8 projects) \\
\hline $\begin{array}{l}\text { Brownfield redevelopment projects in URBAN municipalities } \\
\text { (e.g. Toronto): }\end{array}$ & $\begin{array}{l}0 \%(1 \text { response }) \\
100 \% \text { (2 responses) } \\
80 \% \text { (1 response })\end{array}$ \\
\hline $\begin{array}{l}\text { Brownfield redevelopment projects in SUBURBAN } \\
\text { municipalities (e.g. Oshawa, Hamilton, Guelph): }\end{array}$ & $\begin{array}{l}0 \%(2 \text { responses }) \\
100 \% \text { ( } 1 \text { response }) \\
20 \%(1 \text { response })\end{array}$ \\
\hline $\begin{array}{l}\text { Desired Return on Equity or Internal Rate of Return for } \\
\text { URBAN brownfield redevelopment projects }\end{array}$ & $\begin{array}{l}20 \%(1 \text { response }) \\
25 \%(1 \text { response })\end{array}$ \\
\hline $\begin{array}{l}\text { Desired Return on Equity or Internal Rate of Return for } \\
\text { SUBURBAN brownfield redevelopment projects }\end{array}$ & $20 \%$ (2 responses) \\
\hline Which incentives do you have experience with? & $\begin{array}{l}\text { ESA Study Grants ( } 2 \text { responses) } \\
\text { DC Reductions ( } 1 \text { response) } \\
\text { TAP/BFTIP ( } 2 \text { responses) } \\
\text { TIEGs ( } 3 \text { responses) }\end{array}$ \\
\hline How effective were they? & 5 out of 7 ( 3 responses) \\
\hline
\end{tabular}

As shown, respondents had more experience with urban rather than suburban redevelopments, but had some experience with suburban ones. Their desired ROEs were between $20 \%$ and $25 \%$. Respondents also had experience with a number of incentives (mostly TIEGs), with a positive view of their overall effectiveness. Their views on the effectiveness of individual incentives is shown below: 
Figure 2: Real Estate Professionals: Incentive Effectiveness

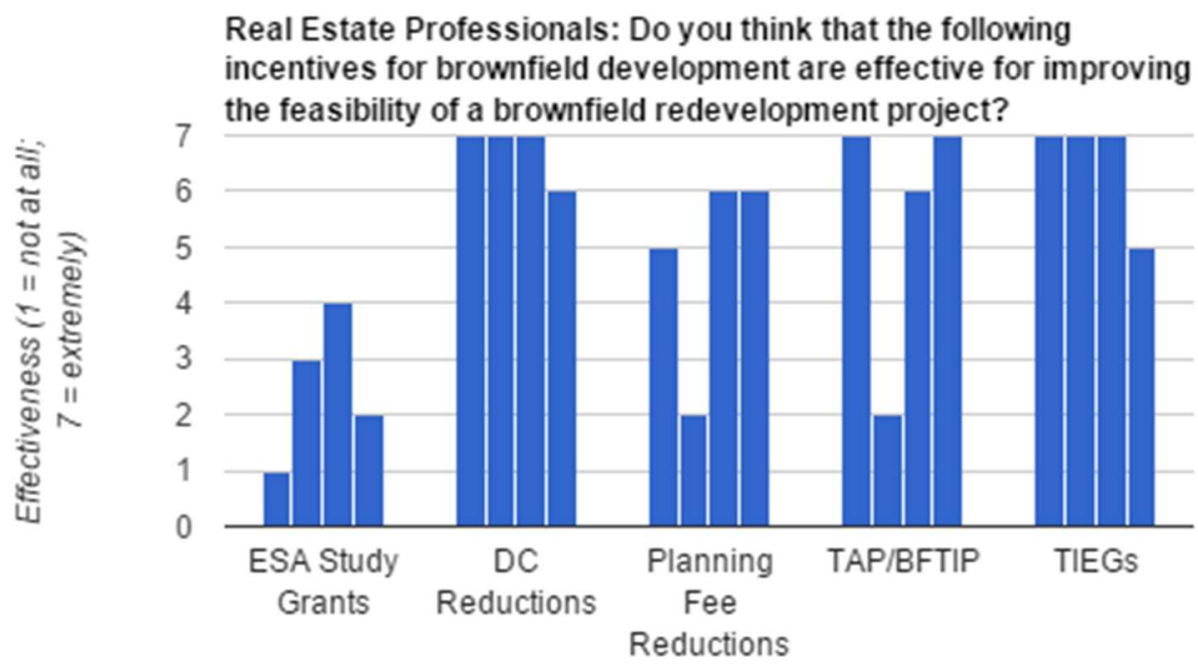

As shown, DC reductions are seen as extremely effective by most respondents, followed closely by TIEGs. Other incentives have a larger range of opinions, with preference for TAP/BFTIPs. ESA study grants were generally viewed as the least effective.

\section{Environmental Remediation Professionals}

Table 9: Environmental Remediation Responses

\begin{tabular}{|l|l|}
\hline Question & Response \\
\hline $\begin{array}{l}\text { How many brownfield redevelopment projects } \\
\text { were completed in the last 5 years in your } \\
\text { company? }\end{array}$ & 0 to 200 projects (median 33) \\
\hline $\begin{array}{l}\text { Of the above, how many brownfield } \\
\text { redevelopments were in URBAN municipalities? }\end{array}$ & 0 to 150 projects (median 23) \\
\hline $\begin{array}{l}\text { Of the above, how many brownfield } \\
\text { redevelopments were in SUBURBAN } \\
\text { municipalities? }\end{array}$ & 0 to 35 projects (median 5) \\
\hline $\begin{array}{l}\text { Remediation Cost Estimates } \\
\text { (BTEX-PHCs, soil and groundwater, dig and dump, 0.2ha site) }\end{array}$ \\
\hline Soil Remediation cost (per cubic metre) & $\$ 45$ to $\$ 130$ (median $\$ 115)$ \\
\hline Groundwater Remediation cost (per cubic metre) & $\$ 30$ to $\$ 2,100$ (median $\$ 200)$ \\
\hline Other fees and disbursements & $\$ 5,000$ to $\$ 910,000$ (median $\$ 67,500)$ \\
\hline Length of time required (months) & 6 to 28 (median 17) \\
\hline
\end{tabular}


As shown, the respondents had a range of experience with brownfield redevelopment, and wide-ranging estimates of cost and time required for remediation. The median values were selected and carried forward to pro forma development, to attempt to reduce the effect of outlier results on overall patterns.

\section{All professionals}

The remainder of the questions were asked of all respondents; their responses were aggregated and shown below.

\section{Stakeholder Support}

First, respondents were asked to rate the supportiveness for local brownfield redevelopment of a variety of stakeholder groups:

"In your opinion, how much support do the following groups have for brownfield redevelopment projects in your municipality?"

Responses are aggregated below:

Table 10: Perceived Stakeholder Support

\begin{tabular}{|c|c|c|c|c|c|c|c|c|c|}
\hline \multirow[b]{2}{*}{$\begin{array}{l}\text { Stakeholder } \\
\text { Groups }\end{array}$} & \multicolumn{7}{|c|}{ How Supportive (1 = not at all; 7 = extremely) } & \multirow{2}{*}{$\begin{array}{l}\text { Total Number } \\
\text { of Responses }\end{array}$} & \multirow{2}{*}{$\begin{array}{l}\text { Weighted } \\
\text { Average } \\
\text { (1 to } 7)\end{array}$} \\
\hline & 1 & 2 & 3 & 4 & 5 & 6 & & & \\
\hline $\begin{array}{l}\text { Remediation } \\
\text { Companies }\end{array}$ & 1 & 1 & 2 & 1 & 2 & 3 & 7 & 17 & 5.29 \\
\hline $\begin{array}{l}\text { Brownfield } \\
\text { Owners }\end{array}$ & 0 & 2 & 1 & 3 & 4 & 5 & 1 & 16 & 4.75 \\
\hline Developers & 2 & 1 & 1 & 2 & 6 & 4 & 1 & 17 & 4.47 \\
\hline $\begin{array}{l}\text { Municipal } \\
\text { Government }\end{array}$ & 1 & 2 & 4 & 0 & 4 & 7 & 0 & 18 & 4.39 \\
\hline Local Residents & 2 & 2 & 1 & 4 & 6 & 2 & 0 & 17 & 3.94 \\
\hline $\begin{array}{l}\text { Lending } \\
\text { Institutions }\end{array}$ & 3 & 4 & 1 & 3 & 4 & 1 & 0 & 16 & 3.25 \\
\hline $\begin{array}{l}\text { Provincial } \\
\text { Government }\end{array}$ & 4 & 3 & 2 & 4 & 3 & 1 & 0 & 17 & 3.12 \\
\hline $\begin{array}{l}\text { Federal } \\
\text { Government }\end{array}$ & 7 & 5 & 2 & 2 & 1 & 0 & 0 & 17 & 2.12 \\
\hline
\end{tabular}

As shown, respondents were generally in agreement that the federal government was not supportive (average score of 2.12). Opinions were more split on provincial support (average score of 3.12) and slightly more positive on municipal governments (average score of 4.39). 
The perceived higher support of municipal government is not too surprising, as most brownfield redevelopment incentives are generally provided by municipalities.

Among non-government organizations, lending institutions were perceived to have somewhat low support (average score of 3.25), while remediation companies had the highest perceived support ${ }^{7}$ with an average score of 5.29 .

\section{Changing Regulatory Processes for Brownfields}

Respondents were then asked to rate the effects of changing regulatory processes, specifically Records of Site Condition (RSCs) on various aspects of brownfield redevelopment. The question was:

"In your opinion, given the changes in the regulatory processes for Record of Site Condition (RSC) for brownfields (after the amendments to O.Reg.153/04 in 2009 to 2011), how have the following aspects of redevelopment projects been affected as a result of these changes?"

Responses are aggregated below:

Table 11: Effects of changes to Record of Site Condition (RSC) regulations

\begin{tabular}{|c|c|c|c|c|c|c|c|c|c|}
\hline \multirow[b]{2}{*}{ Aspects } & \multicolumn{7}{|c|}{$\begin{array}{l}\text { Effect of RSC } \\
(1=\text { much less; } 7 \text { = much more })\end{array}$} & \multirow{2}{*}{$\begin{array}{l}\text { Total Number } \\
\text { of Responses }\end{array}$} & \multirow{2}{*}{$\begin{array}{l}\text { Weighted } \\
\text { Average } \\
\text { (1 to } 7)\end{array}$} \\
\hline & 1 & 2 & 3 & 4 & 5 & 6 & & & \\
\hline $\begin{array}{l}\text { Regulatory Complexity of } \\
\text { Remediation }\end{array}$ & 0 & 0 & 1 & 0 & 6 & 7 & 4 & 18 & 5.72 \\
\hline $\begin{array}{l}\text { Liability Concerns after RSC } \\
\text { filing }\end{array}$ & 0 & 3 & 2 & 8 & 3 & 0 & 2 & 18 & 4.06 \\
\hline $\begin{array}{l}\text { Financial Cost of Remediation } \\
\text { and RSC filing }\end{array}$ & 0 & 0 & 0 & 2 & 4 & 5 & 7 & 18 & 5.94 \\
\hline $\begin{array}{l}\text { Time Required for Remediation } \\
\text { and RSC filing }\end{array}$ & 0 & 0 & 0 & 0 & 2 & 9 & 7 & 18 & 6.28 \\
\hline $\begin{array}{l}\text { Public Approval/Support for } \\
\text { brownfield redevelopment }\end{array}$ & 1 & 1 & 0 & 10 & 4 & 1 & 0 & 17 & 4.06 \\
\hline
\end{tabular}

As shown, brownfield remediation was generally thought to be more complex (5.72), costlier (5.94), and to take much longer (6.28) since before 2009, when substantive amendments to O.Reg. 153/04 increased requirements for environmental site assessment completion and reporting. However, liability concerns and public approval were generally thought to be unchanged as a result of these changes.

\footnotetext{
${ }^{7}$ It is worth noting that most of the respondents were environmental assessment/remediation professionals, so they may have a somewhat biased opinion of their own support.
} 


\section{Planning Policy Changes for Intensification and Brownfields}

Respondents were then asked to rate the effects of changing planning policy on intensification and brownfield redevelopment, specifically the Growth Plan for the Greater Golden Horseshoe and the Greenbelt Plan, on various aspects of brownfield redevelopment. The question was:

"In your opinion, given the changes in planning policy relative to intensification and brownfield redevelopment (specifically the Growth Plan for the Greater Golden Horseshoe, Greenbelt Plan, and other similar policies), how have the following aspects of brownfield redevelopment projects been affected as a result of these changes?"

Responses are aggregated below:

Table 12: Effects of Changes to Planning Policy

\begin{tabular}{|c|c|c|c|c|c|c|c|c|c|}
\hline \multirow[b]{2}{*}{ Aspects } & \multicolumn{7}{|c|}{$\begin{array}{l}\text { Effect of Planning Policy Changes } \\
\text { (1 = much less; } 7 \text { = much more) }\end{array}$} & \multirow{2}{*}{$\begin{array}{l}\text { Total Number } \\
\text { of Responses }\end{array}$} & \multirow{2}{*}{$\begin{array}{l}\text { Weighted } \\
\text { Average } \\
(1 \text { to } 7)\end{array}$} \\
\hline & 1 & 2 & 3 & 4 & 5 & 6 & & & \\
\hline $\begin{array}{l}\text { Change in emphasis [from] } \\
\text { greenfield [to] brownfield }\end{array}$ & 0 & 0 & 1 & 5 & 4 & 6 & 0 & 16 & 4.94 \\
\hline $\begin{array}{l}\text { Regulatory Complexity of } \\
\text { Remediation }\end{array}$ & 0 & 0 & 0 & 3 & 4 & 8 & 3 & 18 & 5.61 \\
\hline $\begin{array}{l}\text { Government Approval/Support } \\
\text { for Brownfield Redevelopments }\end{array}$ & 1 & 3 & 7 & 5 & 1 & 0 & 0 & 17 & 3.12 \\
\hline $\begin{array}{l}\text { Developer Approval/Support for } \\
\text { Brownfield Redevelopments }\end{array}$ & 0 & 3 & 3 & 9 & 2 & 0 & 0 & 17 & 3.59 \\
\hline $\begin{array}{l}\text { Public Approval/Support for } \\
\text { brownfield redevelopment }\end{array}$ & 1 & 2 & 1 & 7 & 6 & 0 & 0 & 17 & 3.88 \\
\hline
\end{tabular}

As shown, a greater emphasis on brownfield redevelopment over greenfields (4.94) was felt, as well as a greater complexity of remediation (5.61); however, support from government (3.12), developers (3.59), and the public (3.88) were felt to have dropped.

This indicates that respondents felt that the Growth Plan, Greenbelt Plan, and other similar policies had increased emphasis on brownfield redevelopment, but that stakeholder support for brownfield redevelopment had not increased. This finding is concerning, as these stakeholders include government, who are behind the change in policy and should conceivably be trying to support the implementation of their own policy.

These policies are currently under review, and the Advisory Panel has recognized that existing environmental and land use legislation is seen as a hurdle by the development industry and an 
impediment to the Province's goals of intensification (Crombie et al, 2015). It is hoped that the review of these documents will reduce this perceived burden.

\section{Urban - Suburban Divide}

Finally, respondents were asked to compare the costs, timeframes, and profitability of urban vs. suburban brownfield redevelopments:

Table 13: Urban vs. Suburban Brownfields: Cost

\begin{tabular}{|c|c|c|c|c|c|c|c|c|c|}
\hline \multirow[b]{2}{*}{ Question } & \multicolumn{6}{|c|}{$\begin{array}{c}\text { Which Costs More } \\
(1=\text { Urban; } 7=\text { Suburban })\end{array}$} & \multirow{2}{*}{\multicolumn{2}{|c|}{$\begin{array}{r}\text { Total Number } \\
7 \text { of Responses }\end{array}$}} & \multirow{2}{*}{$\begin{array}{l}\text { Weighted } \\
\text { Average } \\
(1 \text { to } 7)\end{array}$} \\
\hline & 1 & 2 & 3 & 4 & 5 & 6 & & & \\
\hline $\begin{array}{l}\text { Which Costs } \\
\text { more: Urban or } \\
\text { Suburban } \\
\text { Brownfield } \\
\text { Redevelopment? }\end{array}$ & 4 & 3 & 2 & 6 & 2 & 0 & 0 & 17 & 2.94 \\
\hline
\end{tabular}

$\underline{\text { Table 14: Urban vs. Suburban Brownfields: Timeframe }}$

\begin{tabular}{|c|c|c|c|c|c|c|c|c|c|}
\hline \multirow[b]{2}{*}{ Aspects } & \multicolumn{6}{|c|}{$\begin{array}{l}\text { Which Takes Longer } \\
\text { (1 = Urban; } 7 \text { = Suburban) }\end{array}$} & \multirow{2}{*}{\multicolumn{2}{|c|}{$\begin{array}{r}\text { Total Number } \\
7 \text { of Responses }\end{array}$}} & \multirow{2}{*}{$\begin{array}{l}\text { Weighted } \\
\text { Average } \\
(1 \text { to } 7)\end{array}$} \\
\hline & 1 & 2 & 3 & 4 & 5 & 6 & & & \\
\hline $\begin{array}{l}\text { Which takes } \\
\text { longer: Urban or } \\
\text { Suburban } \\
\text { Brownfield }\end{array}$ & & & & & & & & & \\
\hline Redevelopment? & 2 & 3 & 1 & 10 & 1 & 0 & 0 & 17 & 3.29 \\
\hline
\end{tabular}

Table 15: Urban vs. Suburban Brownfields: Profitability

\begin{tabular}{|c|c|c|c|c|c|c|c|c|c|}
\hline \multirow[b]{2}{*}{ Aspects } & \multicolumn{6}{|c|}{$\begin{array}{l}\text { Which is more profitable } \\
\text { ( } 1 \text { = Urban; } 7 \text { = Suburban) }\end{array}$} & \multirow{2}{*}{\multicolumn{2}{|c|}{$\begin{array}{l}\text { Total Number } \\
7 \text { of Responses }\end{array}$}} & \multirow{2}{*}{$\begin{array}{l}\text { Weighted } \\
\text { Average } \\
(1 \text { to } 7)\end{array}$} \\
\hline & 1 & 2 & 3 & 4 & 5 & 6 & & & \\
\hline $\begin{array}{l}\text { Which is more } \\
\text { profitable: Urban } \\
\text { or Suburban } \\
\text { Brownfield } \\
\text { Redevelopment? }\end{array}$ & 9 & 3 & 1 & 1 & 1 & 1 & 0 & 16 & 2.06 \\
\hline
\end{tabular}

As shown, Urban brownfield redevelopments were thought to cost more (2.94) and take longer (3.29) than suburban brownfields, but to be much more profitable (2.06) in spite of the additional time and cost. 


\section{Pro Forma Analysis}

A pro forma analysis was developed, based on a hypothetical site configuration which could be evaluated given local property markets and incentives in each municipality, in order to provide comparable results. This pro forma is modified from a previously developed scenario of a brownfield redevelopment at 101 Victoria Street West in Whitby, which was drafted for Professor Steven Webber's Urban Investments course at Ryerson University.

\section{Development}

The development of this pro forma was based on several assumptions, primary research, and market research.

\section{Assumptions}

While the pro forma was developed using available market research and figures, several assumptions were made in its development. It is noted that changes to these assumptions could have a great effect on the outcome of the analysis, so the following rationale is given for the estimates made.

Table 16: Pro Forma Assumptions

\begin{tabular}{|l|l|l|}
\hline Item & $\begin{array}{l}\text { Assumed } \\
\text { Value }\end{array}$ & Rationale \\
\hline $\begin{array}{l}\text { Target ROE (Return } \\
\text { on Equity) }\end{array}$ & $20 \%$ & $\begin{array}{l}\text { Based on information from Prof. Steven Webber's Urban } \\
\text { Investments course, and answers from survey respondents, } \\
\text { this represents a desirable profit in Real Estate Development. }\end{array}$ \\
\hline Project size (area) & 0.2 ha & $\begin{array}{l}\text { Approximate size of 101 Victoria Street West in Whitby, which } \\
\text { was used for a base pro forma analysis of former retail fuel } \\
\text { outlets in Urban Investments. Also reportedly the smallest } \\
\text { property size that can feasibly accommodate underground } \\
\text { parking. }\end{array}$ \\
\hline Project building height & 4 storeys & $\begin{array}{l}\text { Based on current new residential developments in the target } \\
\text { municipalities, using February 2016 listings in } \\
\text { www.buzzbuzzhome.com }\end{array}$ \\
\hline $\begin{array}{l}\text { Project building } \\
\text { coverage (\% of } \\
\text { property area) }\end{array}$ & $100 \%$ & $\begin{array}{l}\text { A zero-lot-line development is proposed, consistent with similar } \\
\text { residential developments in urban areas. }\end{array}$ \\
\hline $\begin{array}{l}\text { Building efficiency (\% } \\
\text { of GFA) }\end{array}$ & $85 \%$ & $\begin{array}{l}\text { Based on standard assumptions from Prof. Steven Webber's } \\
\text { Urban Investments course. }\end{array}$ \\
\hline
\end{tabular}




\begin{tabular}{|c|c|c|}
\hline Item & $\begin{array}{l}\text { Assumed } \\
\text { Value }\end{array}$ & Rationale \\
\hline $\begin{array}{l}\text { Construction Schedule } \\
\text { (years) }\end{array}$ & 2 years & $\begin{array}{l}\text { Based on standard assumptions from Prof. Steven Webber's } \\
\text { Urban Investments course. }\end{array}$ \\
\hline $\begin{array}{l}\text { Unit mix (\% of } 1 \\
\text { bedroom units vs. } 2+ \\
\text { bedroom units) }\end{array}$ & $60 \%$ & $\begin{array}{l}\text { Estimated based on market conditions. As market prices were } \\
\text { estimated by } \$ / s f, \text { not per unit, this only affects development } \\
\text { charges and site plan agreements. }\end{array}$ \\
\hline $\begin{array}{l}\text { Soft Costs (as a \% of } \\
\text { hard costs) }\end{array}$ & $30 \%$ & $\begin{array}{l}\text { Based on standard assumptions from Prof. Steven Webber's } \\
\text { Urban Investments course. }\end{array}$ \\
\hline $\begin{array}{l}\text { Previous building size } \\
\text { (for demolition costs) }\end{array}$ & $\begin{array}{l}0 \text { (vacant } \\
\text { lot) }\end{array}$ & $\begin{array}{l}\text { Based on the previous work on } 101 \text { Victoria Street West in } \\
\text { Whitby, and } 651 \text { Queenston Road in Hamilton; only asphalt } \\
\text { and concrete blockades remain on the site. }\end{array}$ \\
\hline $\begin{array}{l}\text { Environmental Study } \\
\text { Cost }\end{array}$ & $\$ 70,000$ & $\begin{array}{l}\text { Rounded assumption for multiple rounds of assessment, } \\
\text { reporting, and filing of Record of Site Condition, based on } \\
\text { answers from survey respondents }\end{array}$ \\
\hline Contaminated depth & $8 \mathrm{~m}$ & $\begin{array}{l}\text { Conservative assumption based on contaminated groundwater } \\
\text { and excavation depth required for two levels of underground } \\
\text { parking }\end{array}$ \\
\hline $\begin{array}{l}\text { Soil Remediation costs } \\
(/ \mathrm{m} 3)\end{array}$ & $\$ 115 / \mathrm{m} 3$ & Rounded unit cost assumption, based on survey responses. \\
\hline $\begin{array}{l}\text { Groundwater } \\
\text { Remediation costs } \\
(/ \mathrm{m} 3)\end{array}$ & $\$ 200 / \mathrm{m} 3$ & $\begin{array}{l}\text { Rounded unit cost assumption, based on survey responses. } \\
\text { The volume of groundwater to be remediated is calculated as } \\
\text { approximately } 30 \% \text { of contaminated soil volume below an } \\
\text { estimated groundwater depth of } 4 \mathrm{~m} \text { (using a standard soil } \\
\text { porosity assumption of } 0.3 \text { ) }\end{array}$ \\
\hline $\begin{array}{l}\text { Remediation Delay } \\
\text { (years) }\end{array}$ & 1 year & $\begin{array}{l}\text { Rounded assumption based on time required to complete } \\
\text { successive assessment rounds and contaminated soil removal, } \\
\text { based on survey responses. }\end{array}$ \\
\hline $\begin{array}{l}\text { Construction Loan } \\
\text { Interest (\% per year) }\end{array}$ & $6 \%$ & $\begin{array}{l}\text { Based on standard assumptions from Prof. Steven Webber's } \\
\text { Urban Investments course. }\end{array}$ \\
\hline $\begin{array}{l}\text { Presale amount (\% of } \\
\text { all units) }\end{array}$ & $85 \%$ & $\begin{array}{l}\text { A combination of figures from Barry Lyon Consulting's August } \\
2011 \text { Lyon Report (RCI \& NBLC, 2011) and figures used in } \\
\text { Urban Investments }\end{array}$ \\
\hline $\begin{array}{l}\text { Remainder Sale } \\
\text { period (years to sell } \\
\text { remainder of units) }\end{array}$ & 2 years & $\begin{array}{l}\text { Based on standard assumptions from Prof. Steven Webber's } \\
\text { Urban Investments course. }\end{array}$ \\
\hline
\end{tabular}


It is understood that these estimates may require revision based on further information; therefore, these figures are highlighted in the pro forma analysis for easy revision.

\section{Brownfield Conditions}

This pro forma is based on a hypothetical former retail fuel outlet, which is approximately 0.2 ha $(2,000$ $\mathrm{m}^{2}$ ), and currently vacant with no structures. This configuration is based on an existing site in Whitby, and is a commonly seen occurrence in suburban municipalities.

Based on previously potentially contaminating uses (gasoline sale and storage), the property would be classified as a brownfield. It should be noted that the property is suspected to be contaminated, but may not be (e.g. if underground storage tanks were competent and did not leak, and no spills reached beneath surface treatments). Financial liabilities for the site are therefore based on the possibility of remediation costs, which must be accounted for before purchasing the site.

It is assumed that approximately $50 \%$ of the property is considered contaminated, to an average depth of $8 \mathrm{~m}$, resulting in a remediation volume of approximately $8000 \mathrm{~m}^{3}$ soil, and $1200 \mathrm{~m}^{3}$ groundwater. Environmental Site Assessment and site remediation (if needed) is therefore expected to cost approximately $\$ 1,230,000$ and take 1 year.

\section{Site location}

The site is assumed to be located at the intersection of arterial roads, near to higher-order transit such as 400 -series highways, with a mix of residential and commercial surrounding uses. In the case of Whitby, the base case for this pro forma is located near a GO station and on a corridor with proposed "mainstreet" style redevelopment plans.

\section{Land Price}

The land price for the site was based on the assessed value of a similar former retail fuel outlet at 651 Queenston Road in Hamilton. The Hamilton property was approximately $0.3 \mathrm{ha}$, and had an assessed value of $\$ 671,500$ or $\$ 222 / \mathrm{m}^{2}$ with no structures remaining. This property was selected based on a visual review of aerial photographs for Hamilton from Google Maps, looking for properties at apparent arterial intersections which appeared to be abandoned former retail fuel outlets.

As it is understood that this value will be different for different markets, an estimate of brownfield land prices in different markets was made by using the relationship between land price in this example $\left(\$ 222 / \mathrm{m}^{2}\right)$ and Hamilton's average condo sale price $\left(\$ 4,511.59 / \mathrm{m}^{2}\right.$, as indicated below). The resulting 
value of $4.92 \%$ was then applied to condo sale prices in other markets to come up with an estimate of market differences in land values.

Residual Land Value was also calculated to control for estimates in land price.

\section{Proposed Development}

The site is proposed to be developed as a multi-residential condominium apartment building, with a height of 4 storeys and approximately 90 units, of which approximately $60 \%$ are assumed to be single-bedroom units. The building is proposed to occupy $100 \%$ of the property area (GSF of 86,111 ). The development is proposed as a "build-and-sell" scenario, where most units are sold prior to construction, and the developer does not intend to retain any interest in the property after development (and sale of the remaining units).

This development is consistent with new developments for sale in the target municipalities ${ }^{8}$

\section{Construction Costs}

Hard costs for the scenarios were taken from the Altus Construction Cost Guide for 2016 (Altus Group, 2016), as an average of Condo/Apartment buildings up to 6 storeys, hybrid concrete/wood construction, including underground parking. Average costs were calculated at $\$ 190 \mathrm{psf}$ for an 86,111 sf building, or approximately $\$ 16.4 \mathrm{M}$. This was checked against an example using RSMeans' Quickcost Estimator ${ }^{9}$ for the proposed scenario, and found to be within $10 \%$ of the Altus estimate.

In addition, local construction cost variations were taken from the Altus Construction Cost Guide for 2016 (Altus Group, 2016), and ranged from $99 \%$ to $115 \%$.

For alternate building scenarios, Altus' costs for 4 storey wood-framed condo were used (Average of $\$ 137.50$ psf). No parking is included in this estimate; a level of underground parking would be an average of $\$ 100$ psf (of building footprint, not GFA). Parking is determined in this scenario in accordance with Whitby By-Law \#6925-14: 1.5 parking spaces are required per unit, and parking spaces must be $5.8 \mathrm{~m}$ by $2.75 \mathrm{~m}$. An efficiency of $60 \%$ is estimated for parking structures, to account for laneways, ramps, posts, etc., giving a total parking garage area of approximately 39,000 sqft, with a cost of approximately $\$ 3.9 \mathrm{M}$. This is generally analogous to the Altus estimate of a 70:30 ratio of above-ground area to buried parking area.

Construction is expected to take 2 years.

\footnotetext{
${ }^{8}$ www.buzzbuzzhome.com

9 www.rsmeans.com
} 


\section{Soft Costs}

Base soft costs (engineering, legal, etc.) were estimated to be $30 \%$ of hard costs.

Additional planning-related costs (Development charges, Zoning bylaw amendments, Site Plan approval, etc.) were determined based on online information from the planning departments of the target municipalities. Zoning Bylaw Amendments and Official Plan Amendments were assumed to be required, based on changing of the property use from commercial (i.e. Gas Station) to multi-residential.

\section{Total Project Costs and Total Loan Amount}

Total costs were calculated as the sum of Land, Hard Costs, Soft Costs, and Environmental (remediation) costs. Using a loan-to-value (LTV) ratio of $80 \%$, the required Equity was deducted, resulting in the loan amount. Simple (i.e. non-compounding) interest on the loan was calculated using a given interest rate of $6 \%$.

\section{Market Research}

Estimates of residential condo sale prices were made based on average new condo sales prices for each target municipality from BuzzBuzzHome (2016). The following averages were used:

Table 17: Average Condo Sale Prices, by Municipality

\begin{tabular}{|l|l|l|l|l|l|l|}
\hline Municipality & Barrie & Guelph & Hamilton & Waterloo & Whitby & $\begin{array}{l}\text { Toronto } \\
\text { (Downtown) }\end{array}$ \\
\hline $\begin{array}{l}\text { New Condo } \\
\text { Sales price }(\$ \\
\text { psf) }\end{array}$ & $\$ 252.78$ & $\$ 362.07$ & $\$ 419.14$ & $\$ 420.48$ & $\$ 374.71$ & $\$ 624.99$ \\
\hline
\end{tabular}

As shown, Toronto's Condo market is significantly higher than the other municipalities considered, due to density, location, and market conditions not discussed in this report. This has the effect of allowing projects to still be profitable with much higher costs than surrounding municipalities.

Originally, both Brantford and Oshawa were included in this analysis. Both of these municipalities were excluded, however, based on not having available current condo development examples which were consistent with the scenario design.

\section{Sale Revenue}

Sale revenue was calculated based on $85 \%$ of units pre-sold at year 0 , and the remainder of units sold after 2 years. The present value of this sale was used, minus carrying costs (i.e. property taxes) on unsold units for the 2 years. 


\section{Project Evaluation}

The pro forma was then used to compare the project in different scenarios, to evaluate their financial feasibility.

\section{Measures of Feasibility}

The measures of feasibility used were Return on Equity and Residual Land Value

\section{Return on Equity (ROE)}

Return on Equity was calculated as the remaining money after project costs and equity are subtracted from sale revenue. This was then shown as a percentage of project equity.

\section{Residual Land Value}

Residual land value was calculated as the residual after project costs (minus land costs) and a preferred ROE of $20 \%$ was subtracted from project sale revenue.

The residual land value represents the highest amount that the developer would be willing to pay for the site, including equity, in order to earn the target ROE of $20 \%$. Were a developer willing to accept a lower percentage of equity as profit, the estimated residual land value would be higher,

\section{Pro Forma Analyses}

\section{Base Case Evaluation: 101 Victoria Street West, Whitby}

Based on the above information, a base case was developed for the brownfield at 101 Victoria Street West in Whitby. While there are risks with generalizing from a specific site, this site was chosen based on its commonplace history as an approximately 0.2 ha vacant former retail fuel outlet, and location on an intersection of arterial roads near higher-order transit and highways. It is proposed that sites similar to this one may be found in the target municipalities. Furthermore, details on revenues and costs relevant to the target municipalities was used where available, as detailed above.

Based on Town of Whitby Report No. PL 45-11 (Town of Whitby, 2011), the property was previously occupied by a Texaco service station. An environmental site assessment (ESA) was conducted by INTERA on September 21, 1993. The property now stands vacant, with limited asphalt surface treatment and surface vegetation. 
The project was assessed for Whitby's market under two scenarios: a greenfield or "clean" development, with no environmental liabilities, and a brownfield redevelopment with environmental liabilities as indicated above. The results of the assessment are shown below:

Table 18: Pro Forma Analysis, Base Case (Whitby)

\begin{tabular}{|l|r|r|}
\hline Item & Whitby (as is) & \multicolumn{1}{l|}{ Whitby (as is) } \\
\hline Project Summary & Greenfield & \multicolumn{1}{l|}{ Brownfield } \\
\hline Land Cost & $-\$ 396,905$ & $-\$ 396,905$ \\
\hline Hard Costs & $-\$ 16,361,144$ & $-\$ 16,361,144$ \\
\hline Soft Costs & $-\$ 6,783,040$ & $-\$ 6,783,040$ \\
\hline Environmental Costs & $\$ 0$ & $-\$ 1,230,000$ \\
\hline Total Project Costs & $-\$ 25,817,739$ & $-\$ 28,364,281$ \\
\hline Sale revenue & $\$ 26,299,066$ & $\$ 26,299,066$ \\
\hline Equity & $-\$ 4,711,266$ & $-\$ 4,958,790$ \\
\hline ROE & $\$ 481,327$ & $-\$ 2,065,215$ \\
\hline ROE \% & $\mathbf{1 0} \%$ & $-42 \%$ \\
\hline Target ROE \% & $20 \%$ & $20 \%$ \\
\hline Target ROE (\$) & $\$ 942,253$ & $\$ 991,758$ \\
\hline Residual Land Value & $-\$ 64,021$ & $-\$ 2,660,068$ \\
\hline
\end{tabular}

As shown, the greenfield scenario of the project has a low ROE (10\%) and negative Residual Land Value at the target of $20 \%$ ROE. While the ROE is positive, the amount of profit would be well below the target ROE, so the project would be considered unfeasible. Since the ROE gap (Target ROE minus ROE) is greater than the land cost, the residual value of the property is considered to be negative; that is, the developer could not pay any land costs and still get the target return.

In the Brownfield scenario, environmental costs as well as project delay are added to the project. As shown, this reduces ROE drastically, by more than $50 \%$ in this scenario. The residual value drops by more than the cost of the remediation, because of the additional costs of carrying the loan and property for an extra year during remediation.

Based on the assumptions and information used, the Residual Land Value is greater than the total environmental costs. Therefore, financial incentives may improve the project performance, but are not expected to be able to make the project feasible on their own. Additional density, reduced construction costs, or higher sale prices could help make the project feasible. 


\section{Comparison between Municipalities (Greenfield Scenarios)}

This development scenario was then compared across all target municipalities, with no environmental costs or delay, to represent a baseline feasibility for the project.

Table 19: Pro Forma Analysis, Greenfield Baseline Comparison

\begin{tabular}{|c|c|c|c|c|c|c|}
\hline Item & Barrie & Guelph & Hamilton & Waterloo & Whitby & Toronto \\
\hline $\begin{array}{l}\text { Project } \\
\text { Summary }\end{array}$ & Greenfield & Greenfield & Greenfield & Greenfield & Greenfield & Greenfield \\
\hline Land Cost & $-\$ 267,753$ & $-\$ 383,517$ & $-\$ 443,967$ & $-\$ 445,386$ & $-\$ 396,905$ & $-\$ 662,010$ \\
\hline Hard Costs & $\$ 16,361,144$ & $\$ 16,361,144$ & $\$ 16,361,144$ & $\$ 16,361,144$ & $\$ 16,361,144$ & $\$ 16,361,144$ \\
\hline Soft Costs & $-\$ 6,949,590$ & $-\$ 6,294,181$ & $-\$ 6,705,075$ & $-\$ 6,540,720$ & $-\$ 6,783,040$ & $-\$ 6,864,137$ \\
\hline $\begin{array}{l}\text { Environmental } \\
\text { Costs }\end{array}$ & $\$ 0$ & $\$ 0$ & $\$ 0$ & $\$ 0$ & $\$ 0$ & $\$ 0$ \\
\hline $\begin{array}{l}\text { Total Project } \\
\text { Costs }\end{array}$ & $\$ 25,853,427$ & $\$ 25,269,979$ & $\$ 25,791,836$ & $\$ 25,611,215$ & $\$ 25,817,739$ & $\$ 26,220,616$ \\
\hline Sale revenue & $\$ 17,705,151$ & $\$ 25,355,677$ & $\$ 29,361,086$ & $\$ 29,440,613$ & $\$ 26,299,066$ & $\$ 43,716,211$ \\
\hline Equity & $-\$ 4,717,779$ & $-\$ 4,611,310$ & $-\$ 4,706,539$ & $-\$ 4,673,579$ & $-\$ 4,711,266$ & $-\$ 4,784,784$ \\
\hline ROE & $-\$ 8,148,276$ & $\$ 85,698$ & $\$ 3,569,250$ & $\$ 3,829,398$ & $\$ 481,327$ & $\$ 17,495,595$ \\
\hline ROE \% & $-173 \%$ & $2 \%$ & $76 \%$ & $82 \%$ & $10 \%$ & $366 \%$ \\
\hline Target ROE \% & $20 \%$ & $20 \%$ & $20 \%$ & $20 \%$ & $20 \%$ & $20 \%$ \\
\hline Target ROE (\$) & $\$ 943,556$ & $\$ 922,262$ & $\$ 941,308$ & $\$ 934,716$ & $\$ 942,253$ & $\$ 956,957$ \\
\hline $\begin{array}{l}\text { Residual Land } \\
\text { Value }\end{array}$ & $-\$ 8,824,079$ & $-\$ 453,048$ & $\$ 3,071,910$ & $\$ 3,340,069$ & $-\$ 64,021$ & $\$ 17,200,648$ \\
\hline
\end{tabular}

As shown, the project has an ROE at or above $20 \%$ in Hamilton, Waterloo, and Toronto, due to higher condo sale revenues in those markets.

The proposed project is unfeasible in Barrie, Guelph, and Whitby. The primary reason for the project being unfeasible in these markets is the low sale revenue relative to project costs. This helps to demonstrate why different development densities and configurations are feasible in different markets. Different approaches may need to be taken in order to encourage higher density developments in these markets.

The poor feasibility of this project in some areas, even without brownfield liabilities, is important because the Growth Plan (2006) directs municipalities in the Greater Golden Horseshoe (including all of the target municipalities, with some special provisions for Barrie) to accommodate additional population through intensification, which specifically includes the redevelopment of brownfields. Developments like this one are an important part of meeting the goals set out by the Growth Plan, so it is important that the provincial 
government and GTHA municipalities recognize the market realities of attempting to encourage higher density built forms where they are not yet supported by stronger real estate markets.

\section{Comparison between Municipalities (Brownfield, No Incentives)}

This development scenario was then compared across all target municipalities, with no financial incentives in a brownfield situation.

Table 20: Pro Forma Analysis, Comparison without Incentives

\begin{tabular}{|c|c|c|c|c|c|c|}
\hline Item & Barrie & Guelph & Hamilton & Waterloo & Whitby & Toronto \\
\hline $\begin{array}{l}\text { Project } \\
\text { Summary }\end{array}$ & $\begin{array}{l}\text { Brownfield, } \\
\text { no CIP }\end{array}$ & $\begin{array}{l}\text { Brownfield, } \\
\text { no CIP }\end{array}$ & $\begin{array}{l}\text { Brownfield, } \\
\text { no CIP }\end{array}$ & $\begin{array}{l}\text { Brownfield, } \\
\text { no CIP }\end{array}$ & $\begin{array}{l}\text { Brownfield, } \\
\text { no CIP }\end{array}$ & $\begin{array}{l}\text { Brownfield, } \\
\text { no CIP }\end{array}$ \\
\hline Land Cost & $-\$ 267,753$ & $-\$ 383,517$ & $-\$ 443,967$ & $-\$ 445,386$ & $-\$ 396,905$ & $-\$ 662,010$ \\
\hline Hard Costs & $\$ 16,361,144$ & $\$ 16,361,144$ & $\$ 16,361,144$ & $\$ 16,361,144$ & $\$ 16,361,144$ & $\$ 16,361,144$ \\
\hline Soft Costs & $-\$ 6,949,590$ & $-\$ 6,294,181$ & $-\$ 6,705,075$ & $-\$ 6,540,720$ & $-\$ 6,783,040$ & $-\$ 6,864,137$ \\
\hline $\begin{array}{l}\text { Environmental } \\
\text { Costs }\end{array}$ & $-\$ 1,230,000$ & $-\$ 1,230,000$ & $-\$ 1,230,000$ & $-\$ 1,230,000$ & $-\$ 1,230,000$ & $-\$ 1,230,000$ \\
\hline $\begin{array}{l}\text { Total Project } \\
\text { Costs }\end{array}$ & $\$ 28,398,767$ & $\$ 27,793,943$ & $\$ 28,341,402$ & $\$ 28,151,804$ & $\$ 28,364,281$ & $\$ 28,797,037$ \\
\hline Sale revenue & $\$ 17,705,151$ & $\$ 25,355,677$ & $\$ 29,361,086$ & $\$ 29,440,613$ & $\$ 26,299,066$ & $\$ 43,716,211$ \\
\hline Equity & $-\$ 4,964,819$ & $-\$ 4,859,081$ & $-\$ 4,954,791$ & $-\$ 4,921,644$ & $-\$ 4,958,790$ & $-\$ 5,034,447$ \\
\hline ROE & $\$ 10,693,615$ & $-\$ 2,438,266$ & $\$ 1,019,685$ & $\$ 1,288,810$ & $-\$ 2,065,215$ & $\$ 14,919,174$ \\
\hline ROE \% & $-215 \%$ & $-50 \%$ & $21 \%$ & $26 \%$ & $-42 \%$ & $296 \%$ \\
\hline Target ROE \% & $20 \%$ & $20 \%$ & $20 \%$ & $20 \%$ & $20 \%$ & $20 \%$ \\
\hline Target ROE (\$) & $\$ 992,964$ & $\$ 971,816$ & $\$ 990,958$ & $\$ 984,329$ & $\$ 991,758$ & $\$ 1,006,889$ \\
\hline $\begin{array}{l}\text { Residual Land } \\
\text { Value }\end{array}$ & $\$ 11,418,826$ & $-\$ 3,026,566$ & $\$ 472,694$ & $\$ 749,867$ & $-\$ 2,660,068$ & $\$ 14,574,295$ \\
\hline
\end{tabular}

As shown, the project still has a positive return on equity in Hamilton, Waterloo, and Toronto, with the largest return in Toronto. Condo sale prices in these municipalities are high enough to make the project still feasible, despite of a drop in ROE \% of approximately $50 \%$ across all scenarios.

However, the ROE in Hamilton is close to the target of $20 \%$, so the project would be considered vulnerable to additional unforeseen costs (like higher remediation costs, delay, or changing project costs). 
Comparison between Municipalities, existing incentives

This development scenario was then compared across all target municipalities, with financial incentives as discussed earlier.

Table 21: Pro Forma Analysis, Comparison with Incentives

\begin{tabular}{|c|c|c|c|c|c|c|}
\hline Item & Barrie & Guelph & Hamilton & Waterloo & Whitby & Toronto \\
\hline Project Summary & $\begin{array}{l}\text { Existing } \\
\text { Incentives }\end{array}$ & $\begin{array}{l}\text { Existing } \\
\text { Incentives }\end{array}$ & $\begin{array}{l}\text { Existing } \\
\text { Incentives }\end{array}$ & $\begin{array}{l}\text { Existing } \\
\text { Incentives }\end{array}$ & $\begin{array}{l}\text { Existing } \\
\text { Incentives }\end{array}$ & $\begin{array}{l}\text { Existing } \\
\text { Incentives }\end{array}$ \\
\hline Land Cost & $-\$ 267,753$ & $-\$ 383,517$ & $-\$ 443,967$ & $-\$ 445,386$ & $-\$ 396,905$ & $-\$ 662,010$ \\
\hline Hard Costs & $-\$ 16,361,144$ & $-\$ 16,361,144$ & $-\$ 16,361,144$ & $-\$ 16,361,144$ & $-\$ 16,361,144$ & $-\$ 16,361,144$ \\
\hline Soft Costs & $-\$ 6,949,590$ & $-\$ 6,294,181$ & $-\$ 6,705,075$ & $-\$ 6,540,720$ & $-\$ 6,783,040$ & $-\$ 6,864,137$ \\
\hline $\begin{array}{l}\text { Environmental } \\
\text { Costs }\end{array}$ & $-\$ 1,230,000$ & $-\$ 1,230,000$ & $-\$ 1,230,000$ & $-\$ 1,230,000$ & $-\$ 1,230,000$ & $-\$ 1,230,000$ \\
\hline $\begin{array}{l}\text { Total Project } \\
\text { Costs }\end{array}$ & $-\$ 28,398,767$ & $-\$ 27,793,943$ & $-\$ 28,341,402$ & $-\$ 28,151,804$ & $-\$ 28,364,281$ & $-\$ 28,797,037$ \\
\hline Study Grant & $\$ 0$ & $\$ 30,000$ & $\$ 25,000$ & $\$ 0$ & $\$ 0$ & $\$ 0$ \\
\hline $\begin{array}{l}\text { Planning Fees } \\
\text { Reduction }\end{array}$ & $\$ 36,500$ & $\$ 0$ & $\$ 0$ & $\$ 0$ & $\$ 0$ & $\$ 0$ \\
\hline DC Exemption & $\$ 0$ & $\$ 0$ & $\$ 0$ & $\$ 0$ & $\$ 0$ & $\$ 0$ \\
\hline TAP/BFTIP & $\$ 0$ & $\$ 26,563$ & $\$ 33,767$ & $\$ 0$ & $\$ 0$ & $\$ 54,944$ \\
\hline TIEG & $\$ 334,151$ & $\$ 648,441$ & $\$ 849,150$ & $\$ 864,413$ & $\$ 0$ & $\$ 491,465$ \\
\hline Incentives & $\$ 370,651$ & $\$ 705,004$ & $\$ 907,916$ & $\$ 864,413$ & $\$ 0$ & $\$ 546,410$ \\
\hline Sale revenue & $\$ 17,705,151$ & $\$ 25,355,677$ & $\$ 29,361,086$ & $\$ 29,440,613$ & $\$ 26,299,066$ & $\$ 43,716,211$ \\
\hline Equity & $-\$ 4,964,819$ & $-\$ 4,859,081$ & $-\$ 4,954,791$ & $-\$ 4,921,644$ & $-\$ 4,958,790$ & $-\$ 5,034,447$ \\
\hline $\begin{array}{l}\text { ROE (Before } \\
\text { Incentives) }\end{array}$ & $-\$ 10,693,615$ & $-\$ 2,438,266$ & $\$ 1,019,685$ & $\$ 1,288,810$ & $-\$ 2,065,215$ & $\$ 14,919,174$ \\
\hline $\begin{array}{l}\text { ROE \% (Before } \\
\text { Incentives) }\end{array}$ & $-215 \%$ & $-50 \%$ & $21 \%$ & $26 \%$ & $-42 \%$ & $296 \%$ \\
\hline $\begin{array}{l}\text { ROE (after } \\
\text { Incentives) }\end{array}$ & $-\$ 10,322,964$ & $-\$ 1,733,262$ & $\$ 1,927,601$ & $\$ 2,153,222$ & $-\$ 2,065,215$ & $\$ 15,465,584$ \\
\hline $\begin{array}{l}\text { ROE \% (After } \\
\text { Incentives) }\end{array}$ & $-208 \%$ & $-36 \%$ & $39 \%$ & $44 \%$ & $-42 \%$ & $307 \%$ \\
\hline $\begin{array}{l}\text { Increase in } \\
\text { ROE \% }\end{array}$ & $7 \%$ & $15 \%$ & $18 \%$ & $18 \%$ & $0 \%$ & $11 \%$ \\
\hline Target ROE \% & $20 \%$ & $20 \%$ & $20 \%$ & $20 \%$ & $20 \%$ & $20 \%$ \\
\hline Target ROE (\$) & $\$ 992,964$ & $\$ 971,816$ & $\$ 990,958$ & $\$ 984,329$ & $\$ 991,758$ & $\$ 1,006,889$ \\
\hline $\begin{array}{l}\text { Residual Land } \\
\text { Value }\end{array}$ & $-\$ 11,048,175$ & $-\$ 2,321,562$ & $\$ 1,380,610$ & $\$ 1,614,280$ & $-\$ 2,660,068$ & $\$ 15,120,705$ \\
\hline
\end{tabular}

As shown, the incentives given have a significant positive effect on the project's ROE, ranging from $7 \%$ (in Barrie) to $18 \%$ (in Hamilton and Waterloo). In the case of Hamilton, the increase in ROE would bring 
the ROE well above $20 \%$ and make the project more feasible. As shown, the TIEG is by far the most valuable incentive, by more than an order of magnitude.

In the case of Whitby, where the ROE is $-42 \%$, it is unlikely that a combination of these incentives would increase the ROE by the required $62 \%$. Furthermore, it is worth noting that the feasibility gap, as determined by the residual land value, is larger than the Environmental Costs, which are generally the maximum eligible for financial incentives. Therefore, the proposed scenario may not be feasible in Whitby with the given information and assumptions, regardless of the environmental liabilities.

\section{Adding Density: A Common Non-Monetary Incentive}

Additional density is used in some incentives for development, such as through s.37 benefits in Toronto. An analysis was performed given additional density ( 2 storeys, or $50 \%$ extra) to see if this would make the project feasible: 
Table 22: Pro Forma Summary, Comparison with Bonus Density

\begin{tabular}{|c|c|c|c|c|c|c|}
\hline Item & Barrie & Guelph & Hamilton & Waterloo & Whitby & Toronto \\
\hline Project Summary & $\begin{array}{l}\text { Bonus } \\
\text { Density }\end{array}$ & $\begin{array}{l}\text { Bonus } \\
\text { Density }\end{array}$ & $\begin{array}{l}\text { Bonus } \\
\text { Density }\end{array}$ & $\begin{array}{l}\text { Bonus } \\
\text { Density }\end{array}$ & $\begin{array}{l}\text { Bonus } \\
\text { Density }\end{array}$ & $\begin{array}{l}\text { Bonus } \\
\text { Density }\end{array}$ \\
\hline Land Cost & $-\$ 267,753$ & $-\$ 383,517$ & $-\$ 443,967$ & $-\$ 445,386$ & $-\$ 396,905$ & $-\$ 662,010$ \\
\hline Hard Costs & $-\$ 24,541,716$ & $-\$ 24,541,716$ & $-\$ 24,541,716$ & $-\$ 24,541,716$ & $-\$ 24,541,716$ & $-\$ 24,541,716$ \\
\hline Soft Costs & $-\$ 10,412,377$ & $-\$ 9,438,242$ & $-\$ 10,028,545$ & $-\$ 9,811,379$ & $-\$ 10,145,562$ & $-\$ 10,284,771$ \\
\hline $\begin{array}{l}\text { Environmental } \\
\text { Costs }\end{array}$ & $-\$ 1,230,000$ & $-\$ 1,230,000$ & $-\$ 1,230,000$ & $-\$ 1,230,000$ & $-\$ 1,230,000$ & $-\$ 1,230,000$ \\
\hline Total Project Costs & $-\$ 41,718,769$ & $-\$ 40,749,323$ & $-\$ 41,502,025$ & $-\$ 41,252,011$ & $-\$ 41,569,581$ & $-\$ 42,068,817$ \\
\hline Incentives & $\$ 537,726$ & $\$ 1,029,224$ & $\$ 1,230,000$ & $\$ 1,230,000$ & $\$ 0$ & $\$ 792,142$ \\
\hline Sale revenue & $\$ 26,557,727$ & $\$ 38,033,516$ & $\$ 44,041,629$ & $\$ 44,160,920$ & $\$ 39,448,598$ & $\$ 65,574,316$ \\
\hline Equity & $-\$ 7,293,491$ & $-\$ 7,124,007$ & $-\$ 7,255,599$ & $-\$ 7,211,890$ & $-\$ 7,267,409$ & $-\$ 7,354,688$ \\
\hline $\begin{array}{l}\text { ROE (Lower } \\
\text { Density) }\end{array}$ & $-\$ 10,322,964$ & $-\$ 1,733,262$ & $\$ 1,927,601$ & $\$ 2,153,222$ & $-\$ 2,065,215$ & $\$ 15,465,584$ \\
\hline $\begin{array}{l}\text { ROE \% (Lower } \\
\text { Density) }\end{array}$ & $-208 \%$ & $-36 \%$ & $39 \%$ & $44 \%$ & $-42 \%$ & $307 \%$ \\
\hline $\begin{array}{l}\text { ROE (Bonus } \\
\text { Density) }\end{array}$ & $-\$ 14,623,315$ & $-\$ 1,686,583$ & $\$ 3,769,604$ & $\$ 4,138,908$ & $-\$ 2,120,983$ & $\$ 24,297,642$ \\
\hline $\begin{array}{l}\text { ROE \% (Bonus } \\
\text { Density) }\end{array}$ & $-200 \%$ & $-24 \%$ & $52 \%$ & $57 \%$ & $-29 \%$ & $330 \%$ \\
\hline $\begin{array}{l}\text { Density Bonus } \\
\text { Effect } \\
\text { on ROE \% }\end{array}$ & $8 \%$ & $12 \%$ & $13 \%$ & $13 \%$ & $13 \%$ & $23 \%$ \\
\hline Target ROE \% & $20 \%$ & $20 \%$ & $20 \%$ & $20 \%$ & $20 \%$ & $20 \%$ \\
\hline Target ROE (\$) & $\$ 1,458,698$ & $\$ 1,424,801$ & $\$ 1,451,120$ & $\$ 1,442,378$ & $\$ 1,453,482$ & $\$ 1,470,938$ \\
\hline $\begin{array}{l}\text { Residual Land } \\
\text { Value }\end{array}$ & $-\$ 15,814,261$ & $-\$ 2,727,868$ & $\$ 2,762,452$ & $\$ 3,141,917$ & $-\$ 3,177,560$ & $\$ 23,488,714$ \\
\hline
\end{tabular}

As shown, if the project is increased by 2 storeys ( $50 \%$ of project total), the project's ROE $\%$ increases by between $8 \%$ and $23 \%$, which is not enough to make the project feasible in Barrie, Guelph, or Whitby. It is noted that the benefit of additional density is weakest in Barrie, where condo sale values are lowest. Therefore, the benefit of extra density is only as good as the local housing market, and may need to be used along with other benefits. 


\section{Extreme Measures: Windsor-Style Incentives}

As listed above, Windsor has interesting incentives, including the ability to "double dip" on eligible costs for DC exemptions. A pro forma of the development for Windsor was run, with the same incentives being applied to Whitby as well.

Table 23: Pro Forma Summary, Comparison with Windsor's Incentives

\begin{tabular}{|c|c|c|}
\hline Item & Windsor & Whitby \\
\hline Project Summary & & Windsor CIP \\
\hline Land Cost & $-\$ 168,948$ & $-\$ 396,905$ \\
\hline Hard Costs & $-\$ 16,361,144$ & $-\$ 16,361,144$ \\
\hline Soft Costs & $-\$ 5,895,321$ & $-\$ 6,783,040$ \\
\hline Environmental Costs & $-\$ 1,230,000$ & $-\$ 1,230,000$ \\
\hline Total Project Costs & $-\$ 27,080,883$ & $-\$ 28,364,281$ \\
\hline Study Grant & $\$ 25,000$ & $\$ 25,000$ \\
\hline Planning Fees Reduction & $\$ 0$ & $\$ 0$ \\
\hline DC Exemption & $\$ 578,758$ & $\$ 1,077,653$ \\
\hline TAP/BFTIP & $\$ 16,689$ & $\$ 22,863$ \\
\hline TIEG & $\$ 988,070$ & $\$ 1,156,650$ \\
\hline Incentives & $\$ 1,608,516$ & $\$ 2,282,166$ \\
\hline Sale revenue & $\$ 11,245,202$ & $\$ 26,299,066$ \\
\hline Equity & $-\$ 4,734,420$ & $-\$ 4,958,790$ \\
\hline ROE (Before Incentives) & $-\$ 15,835,682$ & $-\$ 2,065,215$ \\
\hline ROE \% (Before Incentives) & $-334 \%$ & $-42 \%$ \\
\hline ROE (after Incentives) & $-\$ 14,227,166$ & $\$ 216,951$ \\
\hline ROE \% (After Incentives) & $-301 \%$ & $4 \%$ \\
\hline Increase in ROE \% & $34 \%$ & $46 \%$ \\
\hline Target ROE \% & $20 \%$ & $20 \%$ \\
\hline Target ROE (\$) & $\$ 946,884$ & $\$ 991,758$ \\
\hline Residual Land Value & $-\$ 15,005,102$ & $-\$ 377,902$ \\
\hline
\end{tabular}

As shown, this project would be very unfeasible in Windsor, given the very low condo sale value of $\$ 159.50$ psf, and higher construction costs. However, Windsor's incentives still increase the ROE by $34 \%$, which is nearly double the increase of other scenarios. Of note, this includes a TIEG on both the Municipal AND Regional share of the property tax increment (which would therefore require regional approval as well as local). 
In the case of Whitby, the ROE increases by $46 \%$, and the project moves into positive ROE territory. An additional $16 \%$ ROE (approximately $\$ 800,000$ ) would be required to make this project feasible with the current land costs. Options to increase the performance of this project could include waiving the remaining costs on DCs (Total DC fee is $\$ 1.8 \mathrm{M}$, allowing an additional $\$ 700 \mathrm{k}$ to be added to the balance of the project) or by the developer changing the project configuration to reduce costs and increase value.

It is noted that in this case, the Whitby project would be paying out incentives equal to roughly twice the environmental costs. These additional costs would need to be weighed against the benefits of the development. Were the environmental costs greater, greater grants could be given as TIEGs, or through DC reductions. Conversely, limits on either of these grants could be raised to encourage projects like this.

\section{Reducing Land Costs}

The previous scenarios have included land costs for the development, based on the assessed value of a similar property. However, it is arguable that the previous owner should be financially responsible for the pollution on their property. Furthermore, property owners should not be incentivized to hold a vacant brownfield and prevent development while waiting for nearby property prices to rise in order to make a higher profit. Depending on the case, municipalities may take possession of lands where property taxes are unpaid for 2 years. In these cases, (or by other means) a sale of the property could be arranged for $\$ 1$. A pro forma of the development was run, given Windsor-style incentives and a sale price of $\$ 1$. 
Table 24: Pro Forma Summary, Sale Price of $\$ 1$ and Windsor's Incentives

\begin{tabular}{|c|c|c|}
\hline Item & $\begin{array}{l}\text { Whitby } \\
\text { (Windsor CIP) }\end{array}$ & $\begin{array}{l}\text { Whitby } \\
\text { (\$1, Windsor CIP) }\end{array}$ \\
\hline \multicolumn{3}{|l|}{ Project Summary } \\
\hline Land Cost & $-\$ 396,905$ & $-\$ 1$ \\
\hline Hard Costs & $-\$ 16,361,144$ & $-\$ 16,361,144$ \\
\hline Soft Costs & $-\$ 6,783,040$ & $-\$ 6,783,040$ \\
\hline Environmental Costs & $-\$ 1,230,000$ & $-\$ 1,230,000$ \\
\hline Total Project Costs & $-\$ 28,364,281$ & $-\$ 27,910,223$ \\
\hline Study Grant & $\$ 25,000$ & $\$ 25,000$ \\
\hline Planning Fees Reduction & $\$ 0$ & $\$ 0$ \\
\hline DC Exemption & $\$ 1,077,653$ & $\$ 1,077,653$ \\
\hline TAP/BFTIP & $\$ 22,863$ & $\$ 22,863$ \\
\hline TIEG & $\$ 1,156,650$ & $\$ 1,156,650$ \\
\hline Incentives & $\$ 2,282,166$ & $\$ 2,282,166$ \\
\hline Sale revenue & $\$ 26,299,066$ & $\$ 26,299,066$ \\
\hline Equity & $-\$ 4,958,790$ & $-\$ 4,879,410$ \\
\hline ROE (Before Incentives) & $-\$ 2,065,215$ & $-\$ 1,611,157$ \\
\hline ROE \% (Before Incentives) & $-42 \%$ & $-33 \%$ \\
\hline ROE (after Incentives) & $\$ 216,951$ & $\$ 671,009$ \\
\hline ROE \% (After Incentives) & $4 \%$ & $14 \%$ \\
\hline Increase in ROE \% & $46 \%$ & $47 \%$ \\
\hline Target ROE \% & $20 \%$ & $20 \%$ \\
\hline Target ROE (\$) & $\$ 991,758$ & $\$ 975,882$ \\
\hline Residual Land Value & $-\$ 377,902$ & $-\$ 304,872$ \\
\hline
\end{tabular}

As shown, in this scenario the reduction in land cost makes a significant impact on the project ROE (-33\% at $\$ 1$ land value vs. $-43 \%$ at regular land value). After incentives, this scenario has an ROE of $14 \%$, which is much closer to the target ROE of $20 \%$.

Transferring property at $\$ 1$ should be considered to be an important and valuable incentive. Municipalities can do this in the case of tax sale properties, and may use other methods such as higher property taxes on vacant properties to discourage brownfield owners from trying to wait for a profitable deal on their properties. 


\section{Alternate Scenario: Wood building, Windsor-Style Incentives}

Different building materials had different project costs. Changes to the Ontario building code now allow for buildings up to 6 storeys to be built with wooden frames ${ }^{10}$. The scenario was adjusted to use Altus' costing for wooden frame buildings, including an additional amount for underground parking, in addition to Windsor's incentives:

Table 25: Pro Forma Summary, Comparison with Hybrid and Wooden Construction

\begin{tabular}{|c|c|c|}
\hline Item & Whitby (Windsor CIP) & Whitby (Windsor CIP) \\
\hline Project Summary & $\begin{array}{l}\text { Hybrid Construction, including } \\
\text { underground parking }\end{array}$ & $\begin{array}{l}\text { Wooden Construction, } \\
\text { underground parking added }\end{array}$ \\
\hline Land Cost & $-\$ 396,905$ & $-\$ 396,905$ \\
\hline Hard Costs & $-\$ 16,361,144$ & $-\$ 15,763,141$ \\
\hline Soft Costs & $-\$ 6,783,040$ & $-\$ 6,603,639$ \\
\hline Environmental Costs & $-\$ 1,230,000$ & $-\$ 1,230,000$ \\
\hline Total Project Costs & $-\$ 28,364,281$ & $-\$ 27,474,932$ \\
\hline Study Grant & $\$ 25,000$ & $\$ 25,000$ \\
\hline Planning Fees Reduction & $\$ 0$ & $\$ 0$ \\
\hline DC Exemption & $\$ 1,077,653$ & $\$ 1,077,653$ \\
\hline TAP/BFTIP & $\$ 22,863$ & $\$ 22,863$ \\
\hline TIEG & $\$ 1,156,650$ & $\$ 1,156,650$ \\
\hline Incentives & $\$ 2,282,166$ & $\$ 2,282,166$ \\
\hline Sale revenue & $\$ 26,299,066$ & $\$ 26,299,066$ \\
\hline Equity & $-\$ 4,958,790$ & $-\$ 4,803,310$ \\
\hline ROE (Before Incentives) & $-\$ 2,065,215$ & $-\$ 1,175,866$ \\
\hline ROE \% (Before Incentives) & $-42 \%$ & $-24 \%$ \\
\hline ROE (after Incentives) & $\$ 216,951$ & $\$ 1,106,300$ \\
\hline ROE \% (After Incentives) & $4 \%$ & $23 \%$ \\
\hline Increase in ROE \% & $46 \%$ & $48 \%$ \\
\hline Target ROE \% & $20 \%$ & $20 \%$ \\
\hline Target ROE (\$) & $\$ 991,758$ & $\$ 960,662$ \\
\hline Residual Land Value & $-\$ 377,902$ & $\$ 542,543$ \\
\hline
\end{tabular}

10 http://www.mah.gov.on.ca/Asset11186.aspx?method=1 
As shown, this scenario finally has the project ROE over $20 \%$ (after incentives). The ROE before incentives is still negative, and approximately equal to the environmental costs. Therefore, incentives greater than the eligible environmental costs were required to make this project feasible.

Switching the construction method to wood reduced the hard costs for the project by approximately $\$ 600,000$. This in turn reduces soft costs, reducing the total project costs by approximately $\$ 900,000$. This reduces the equity required, which further reduces the ROE threshold required to make the project feasible.

Incentives like Windsor's, which allow "double-dipping" on eligibly environmental costs, are a much stronger incentive for enabling brownfield development. More significantly, they can enable a project to go forward with a built form or density which would not currently be feasible in that market, even on a greenfield site. 


\section{Developing a Brownfields CIP for Whitby, Ontario}

This section reviews Whitby-specific CIP incentives, as per incentives recommended in 2008, and a draft CIP released in 2015 for a secondary plan area. A list of incentives was recommended, to be added to a proposed CIP for the entire urban area, based on the results of the pro-forma analysis in the previous section.

\section{Whitby CIP Incentives}

\section{Existing CIP Incentives}

The Town of Whitby has a CIP for the downtown area, dated 2004. This CIP is primarily for small capital improvements to encourage restoration of historic architectural features, with associated small grants (less than $\$ 5 \mathrm{k}$ ); there are no incentives specifically targeted at brownfield redevelopment (Whitby, 2004).

\section{Durham Regional Revitalization Program (RRP)}

The Region of Durham established the RPP in 2008 to provide matching funding to area municipalities for revitalization projects (Durham, 2015). This is funded through the Regional Revitalization Reserve Fund, which is reportedly replenished through increased assessment of approved CIP projects.

Criticisms of the RRP include the requirement of the lower-tier municipality to advocate for the proponent in order to secure funding; this includes preparing a business case demonstrating the remaining feasibility gap after local CIP incentives have been applied, and ongoing monitoring of the project by the lower-tier municipality. This can potentially put the lower-tier municipality in a conflict of interest, and demands additional public resources be used to secure assistance for private development.

The complexity of the current RRP requirements makes it an unlikely ${ }^{11}$ source of funding, except in the case of very large developments which are seen as a high local priority.

\section{Proposed CIP Incentives - 2008}

In 2008, IBI group prepared a report for the Town of Whitby with recommended additions to its CIP (IBI, 2008). This was based on expanding the existing program in order to attract additional development. Additional recommended incentives including the following:

- TIEG: Maximum $80 \%$ of increment for 10 years

- Building Permit Fee Equivalent Grant: Maximum $80 \%$ of permit fees

${ }^{11}$ Based on discussions with Whitby Planning and Development staff over the Summer 2015 work term. 
- DC Exemption: Maximum $50 \%$ of DCs

The 2008 report also included recommended budget information for some of the recommended grants; however, budgeting for the above was not completed, as these grants were reportedly calculated as foregone revenue, and would be highly variable, depending on the number and type of applications granted by council (IBI, 2008). Of special note is that IBI noted that Tax Increment Grant costs were for a limited period with a long-term payback.

The 2008 report was commented on by staff in 2012 , including a recommendation to draft a report to council regarding implementation strategies (Whitby, 2012).

\section{Proposed CIP Incentives - 2015}

Whitby released a proposed Community Improvement Plan for the Port Whitby Secondary Plan Area in 2015; this was developed alongside a proposed official plan update for the secondary plan area, to incorporate Growth Plan objectives and the Port Whitby Sustainable Community Plan (PWSCP).

The CIP identifies a priority area for brownfield redevelopment, which is focused on a single property on the south waterfront; however, the incentives listed in the CIP may be applied to other eligible properties within the Community Improvement Project Area (CIPA), which includes other brownfields within the Port Whitby Community Secondary Plan.

The Community Improvement Plan is targeted at a variety of development goals, but includes specific incentives for brownfield redevelopment, including the following:

\section{Development Charge Reduction}

The development charge grant would be equivalent to the eligible costs of assessment and cleanup, with no stated maximum. This incentive would apply to the proposed brownfield CIPA. It is noted that many CIPs include a maximum on the development charge reduction, usually expressed as a percentage, to limit the amount of the incentive.

\section{Tax Assistance Program (TAP) and Tax Increment Equivalent Grant (TIEG)}

The proposed CIP includes tax incentives which can be applied to brownfield priority area as well as the CIPA (even though the summary portion of the CIP says that this incentive is not applicable outside of the brownfield priority area). These incentives are labelled Brownfields Property Tax Assistance, but functions as a TAP and TIEG.

The TAP and TIEG incentives are between $80 \%$ of the tax increment for the property, increasing to $100 \%$ for projects which achieve LEED certification or that follow the Port Whitby Sustainable Community Plan 
(PWSCP) requirements for green design. The TAP incentive lasts a maximum of 3 years, and the TIEG stays at $100 \%$ of the tax increment for a maximum duration of 5 years from project completion ${ }^{12}$.

The TAP and TIEG incentives share a maximum project budget of $\$ 100,000$ annually for all accepted projects. It should be noted that in the pro forma analysis section, the tax increment was approximately $\$ 213,000$ for this project. This would effectively reduce the TIEG incentive to approximately $45 \%$. Furthermore, the annual budget is presumed to be shared across all projects; therefore, it would be unlikely that the project would get this much TIEG if other projects were underway.

One issue with the proposed funding is that any project which achieves minimum LEED certification would get a TIEG to cover expenses; it is not indicated clearly whether the additional TIEG for LEED would only be applicable where brownfield redevelopment occurs. This should be made clear in order to close any loopholes which could encourage minimal LEED compliance while comparatively discouraging brownfield redevelopment.

\section{Other Incentives}

The proposed CIP also includes other incentives not targeted at brownfield redevelopment costs, such as facade grants. These were not reviewed.

\section{Recommended Incentives}

It is recommended that a CIP for Whitby be tiered such that some incentives are available only in priority areas. It is recommended that these priority areas by generally analogous to designated intensification corridors and central areas, as well as specific brownfield sites identified by Whitby, where the targeted incentives can have the greatest effect on the local economy and on implementing Official Plan objectives.

\section{All CIP areas}

Based on the other CIPs reviewed, the pro forma analysis, and the tools available to Whitby, it is recommended that the following incentives be offered as part of a CIP which would apply to the entire municipality:

- An ESA study grant (50\%, maximum grant of $\$ 25,000$ per project); and

- A TIEG of $80 \%$ to $100 \%$ of both the lower and upper tier tax increment.

Furthermore, the remaining $20 \%$ of the tax increment should be diverted into a reserve fund for use in funding other CIP grants, including Study Grants. This way, the future budget for CIP incentives may be

12 The summary table of the CIP lists the TAP/TIEG duration as 10 years. The CIP also notes that a maximum combined duration of 12 years may apply for combining TAP/TIEG assistance and development grants. This is assumed to be in error, as this should generally be a maximum of 3 years TAP assistance, and 10 years TIEG assistance. 
replenished by tax increases from ongoing brownfield redevelopments. In addition, it is recommended that projects which achieve specific goals set out by the Official Plan be considered for a grant on the remaining $20 \%$. These goals could include implementation of Urban Design Guidelines, Community Sustainability Plan guidelines, Intensification Area guidelines, etc.

\section{Priority Areas}

The incentives which represent a large direct expenditure or loss by the municipality (e.g.: DC exemptions, TAP and BFTIP) can be restricted to these priority areas. Core incentives such as the ESA Study Grant and TIEG can be applied to the entire municipality.

Priority areas or properties may be defined by Whitby as those where redevelopments have an opportunity to achieve goals or act as a catalyst of desired change in the area.

The recommended incentives for Priority Areas are as follow:

- A Feasibility Study Grant (50\% costs, maximum grant of $\$ 5,000)$, similar to the City of Windsor's;

- A DC Exemption of $50 \%$, not to reduce the eligible expenses for other incentives, similar to the City of Windsor's CIP; and

- A TAP/BFTIP of $100 \%$, to include the regional property tax as well as lower tier and education.

The recommended incentives are summarized below:

Table 26: Summary of Recommended CIP Incentives for Whitby

\begin{tabular}{|c|c|c|c|c|c|}
\hline Incentive & $\begin{array}{l}\text { Feasibility } \\
\text { Study Grant }\end{array}$ & $\begin{array}{l}\text { ESA Study } \\
\text { Grant }\end{array}$ & $\begin{array}{l}\text { DC } \\
\text { Exemption }\end{array}$ & TAP / BFTIP & TIEG \\
\hline Amount & $\begin{array}{l}50 \% \text { of costs } \\
\operatorname{Max} \$ 5,000\end{array}$ & $\begin{array}{l}50 \% \text { of costs } \\
\text { Max } \$ 25,000\end{array}$ & $\begin{array}{l}50 \% \text { of DC } \\
\text { (not to reduce } \\
\text { eligible } \\
\text { expenses) }\end{array}$ & $100 \%$ & $\begin{array}{l}80 \% \\
+20 \% \text { for OP } \\
\text { Implementatio } \\
n\end{array}$ \\
\hline Duration & & & & up to 3 years & up to 10 years \\
\hline $\begin{array}{l}\text { Time } \\
\text { released }\end{array}$ & $\begin{array}{l}\text { At completion of } \\
\text { Study }\end{array}$ & $\begin{array}{l}\text { At completion of } \\
\text { Study }\end{array}$ & $\begin{array}{l}\text { At time of } \mathrm{DC} \\
\text { payment }\end{array}$ & $\begin{array}{l}\text { during } \\
\text { development } \\
\text { period }\end{array}$ & $\begin{array}{l}\text { Yearly, after } \\
\text { development } \\
\text { and } \\
\text { reassessment }\end{array}$ \\
\hline $\begin{array}{l}\text { Eligible } \\
\text { Areas }\end{array}$ & $\begin{array}{l}\text { Priority Areas } \\
\text { only }\end{array}$ & All CIP Areas & $\begin{array}{l}\text { Priority Areas } \\
\text { only }\end{array}$ & $\begin{array}{l}\text { Priority Areas } \\
\text { only }\end{array}$ & All CIP Areas \\
\hline
\end{tabular}


It should be noted that this recommendation is based off information gleaned from available CIPs; the 2008 IBI report has a detailed summary of various incentives offered by Ontario municipalities, which could be updated for a more complete recommendation.

\section{Budgeting for incentives}

The 2015 Capital Budget for Whitby is approximately $\$ 26 \mathrm{M}$, which includes an amount of $\$ 239,000$ for Downtown Improvement (Whitby, 2015a). This includes Whitby's current CIP budget of $\$ 40,000$, which is allocated to the Downtown Facade Improvement Program (as per current CIP incentives), and a one-time expenditure of $\$ 50,000$ for Downtown Revitalization.

It is recommended that an annual reserve of $\$ 75,000$ be added for ESA Study Grants and Feasibility Studies, to be renewed for 5 years and then replenished by $20 \%$ of the tax increment on completed redevelopments, which would be retained by the Town (given an $80 \%$ TIEG). This fund could eventually be used for additional efforts such as Municipal action (i.e. cancellation of tax arrears, ESAs, and/or remediation) on Tax Sale properties, in order to prepare them for development.

It is noted that the 2008 IBI report indicated that budgeting for TIEG, Planning Fee, and DC reduction expenditures was not based on allocated capital funds, but on foregone revenue. ${ }^{13}$ For the purposes of this study, TIEG incentives are considered to be less costly to the Town of Whitby than are DC exemptions or Planning fee exemptions, as they are spread out over a longer period (up to 10 years for TIEG) and can not exceed the increase in municipal taxes payable from the project. Furthermore, they are a "pay-as-you-go" grant, where grant money is given only after the full taxes (including the tax increment) have been paid.

\footnotetext{
${ }^{13}$ While this may be true, it can be argued that the services required in the projects, which would normally be funded through these fees, will require funds to be allocated from higher fees elsewhere or from a reduction in expenditures.
} 


\section{Comparison of Whitby CIP Incentive Scenarios}

The different CIP scenarios discussed above are compared in Table 2, below.

Table 27: Summary of Whitby's CIP incentives scenarios

\begin{tabular}{|l|l|l|l|l|}
\hline Version & Current ${ }^{14}$ & $\begin{array}{l}\text { 2008 IBI } \\
\text { Report }\end{array}$ & 2015 Draft CIP & Recommended \\
\hline Scope & $\begin{array}{l}\text { Downtown } \\
\text { Whitby }\end{array}$ & $\begin{array}{l}\text { Whitby + } \\
\text { Brooklin }\end{array}$ & $\begin{array}{l}\text { Port Whitby } \\
\text { Secondary Plan }\end{array}$ & $\begin{array}{l}\text { Whitby + Brooklin (Urban } \\
\text { Boundary) }\end{array}$ \\
\hline $\begin{array}{l}\text { Rehabilitation } \\
\text { Feasibility Study }\end{array}$ & & & $\begin{array}{l}\text { \$5k Max per property, Priority } \\
\text { Areas Only }\end{array}$ \\
\hline ESA Study Grant & & $80 \%$ Max & \$25k Max per property \\
\hline $\begin{array}{l}\text { Building Permit } \\
\text { Grant }\end{array}$ & & $50 \%$ Max & Eligible Costs & $\begin{array}{l}50 \% \text { Max, Priority Areas only } \\
\text { (Does not reduce eligible } \\
\text { amount) }\end{array}$ \\
\hline $\begin{array}{l}\text { Development } \\
\text { Charge Reduction }\end{array}$ & & & Max 3 years & $\begin{array}{l}100 \% \text { Max Cancellation } \\
3 \text { Years Max, Priority Areas } \\
\text { only }\end{array}$ \\
\hline $\begin{array}{l}\text { TAP (Municipal } \\
\text { Tax Cancellation) }\end{array}$ & & Recommended & $\begin{array}{l}\text { Pending } \\
\text { Provincial }\end{array}$ & $\begin{array}{l}100 \% \text { Max Cancellation } \\
\text { Approval } \\
\text { only (Provincial Approval } \\
\text { required) }\end{array}$ \\
\hline $\begin{array}{l}\text { BFTIP (Education } \\
\text { Tax Cancellation) }\end{array}$ & & $80 \%$ Max & $\begin{array}{l}80 \% \text { (100\% if } \\
\text { LEED/PWSCP) }\end{array}$ & $\begin{array}{l}80 \% \text { Max } \\
+20 \% \text { for LEED or PWSCP }\end{array}$ \\
\hline $\begin{array}{l}\text { TIEG (Tax } \\
\text { Increment Grant) }\end{array}$ & & & &
\end{tabular}

\footnotetext{
${ }^{14}$ No Brownfield related incentives. The current Community Improvement Plan is for Facade and Design grants, with a combined maximum of $\$ 3,500$ per project, with no more than one of each project every three years.
} 
A final pro forma analysis was run of the project, based on these four scenarios for Whitby in the alternate (wooden) construction scenario:

Table 28: Pro Forma Analysis, Alternate Construction, Comparison of Incentives

\begin{tabular}{|c|c|c|c|c|}
\hline Item & Whitby & Whitby & Whitby & Whitby \\
\hline Project Summary & $\begin{array}{l}\text { Current (no } \\
\text { incentives) }\end{array}$ & $\begin{array}{l}2008 \text { Rec. } \\
\text { Incentives }\end{array}$ & $\begin{array}{l}2015 \text { Draft CIP } \\
\text { Incentives }\end{array}$ & $\begin{array}{l}\text { Recommended CIP } \\
\text { Incentives, Priority Area }\end{array}$ \\
\hline Land Cost & $-\$ 396,905$ & $-\$ 396,905$ & $-\$ 396,905$ & $-\$ 396,905$ \\
\hline Hard Costs & $-\$ 15,763,141$ & $-\$ 15,763,141$ & $-\$ 15,763,141$ & $-\$ 15,763,141$ \\
\hline Soft Costs & $-\$ 6,603,639$ & $-\$ 6,603,639$ & $-\$ 6,603,639$ & $-\$ 6,603,639$ \\
\hline Environmental Costs & $-\$ 1,230,000$ & $-\$ 1,230,000$ & $-\$ 1,230,000$ & $-\$ 1,230,000$ \\
\hline Total Project Costs & $-\$ 27,474,932$ & $-\$ 27,474,932$ & $-\$ 27,474,932$ & $-\$ 27,474,932$ \\
\hline Study Grant & $\$ 0$ & $\$ 0$ & $\$ 0$ & $\$ 25,000$ \\
\hline Planning Fees & $\$ 0$ & $\$ 62,887$ & $\$ 0$ & $\$ 0$ \\
\hline DC Exemption & $\$ 0$ & $\$ 898,044$ & $\$ 1,230,000$ & $\$ 1,205,000$ \\
\hline TAP/BFTIP & $\$ 0$ & $\$ 0$ & $\$ 0$ & $\$ 22,863$ \\
\hline TIEG & $\$ 0$ & $\$ 269,069$ & $\$ 0$ & $\$ 1,182,137$ \\
\hline Incentives & $\$ 0$ & $\$ 1,230,000$ & $\$ 1,230,000$ & $\$ 2,435,000$ \\
\hline Sale revenue & $\$ 26,299,066$ & $\$ 26,299,066$ & $\$ 26,299,066$ & $\$ 26,299,066$ \\
\hline Equity & $-\$ 4,803,310$ & $-\$ 4,803,310$ & $-\$ 4,803,310$ & $-\$ 4,803,310$ \\
\hline $\begin{array}{l}\text { ROE (Before } \\
\text { Incentives) }\end{array}$ & $-\$ 1,175,866$ & $-\$ 1,175,866$ & $-\$ 1,175,866$ & $-\$ 1,175,866$ \\
\hline $\begin{array}{l}\text { ROE \% (Before } \\
\text { Incentives) }\end{array}$ & $-24 \%$ & $-24 \%$ & $-24 \%$ & $-24 \%$ \\
\hline $\begin{array}{l}\text { ROE (after } \\
\text { Incentives) }\end{array}$ & $-\$ 1,175,866$ & $\$ 54,134$ & $\$ 54,134$ & $\$ 1,259,134$ \\
\hline $\begin{array}{l}\text { ROE \% (After } \\
\text { Incentives) }\end{array}$ & $-24 \%$ & $1 \%$ & $1 \%$ & $26 \%$ \\
\hline Increase in ROE \% & $0 \%$ & $26 \%$ & $26 \%$ & $51 \%$ \\
\hline Target ROE \% & $20 \%$ & $20 \%$ & $20 \%$ & $20 \%$ \\
\hline Target ROE (\$) & $\$ 960,662$ & $\$ 960,662$ & $\$ 960,662$ & $\$ 960,662$ \\
\hline $\begin{array}{l}\text { Residual Land } \\
\text { Value }\end{array}$ & $-\$ 1,739,623$ & $-\$ 509,623$ & $-\$ 509,623$ & $\$ 695,377$ \\
\hline
\end{tabular}

As shown, neither the 2008 recommended incentives nor the 2015 draft CIP for Port Whitby increase the ROE enough to make the project feasible with current assumptions, even though they both increase the ROE by $26 \%$, and have the same resulting residual land value. This is because although the 2008 and 2015 incentives are different, they are both limited to the eligible costs of redevelopment, which is the 
amount of the Environmental Costs. The TAP/BFTIP and TIEG under the 2015 CIP do not have an effect on this scenario, because the DC exemption is already greater than the eligible environmental costs.

The 2008 recommended incentives have a variety of incentives which are used for the maximum eligible amount; however, this amount is not enough to make the project feasible.

The 2015 Draft CIP also includes a TIEG of $80 \%$ to $100 \%$, maxing out at $\$ 100,000$ per year (PV of approximately $\$ 300,000$ ); however, the eligible amount is taken up by the DC reduction at approximately $70 \%$ and therefore the TIEG does not contribute any amount to the project.

The recommended incentives would be sufficient to make this project feasible with an additional $6 \%$ margin. These incentives are able to do so primarily because the DC exemption does not subtract from the eligible expenses, although it cannot exceed the total eligible expenses on its own. This makes brownfield development more profitable than greenfield development, by allowing incentives above the total environmental remediation costs. While this represents additional costs to the municipality, this also represents an opportunity for Whitby to turn brownfield properties into "pilot" properties, which by virtue of their increased profitability can be the first to draw new development which implements OP goals.

It should be noted that the land costs used in this analysis were still based on the available example from Hamilton; current assessed value for the Whitby property was not available. 


\section{Piloting CIP Incentives}

It is recommended that the property at 101 Victoria Street West in Whitby be used as a pilot project for brownfield redevelopment financial incentives in Whitby, and in Port Whitby in Particular. Maps of this location in relation to the Town of Whitby, and surrounding property uses is shown below:

\section{Figure 3: Property Location}

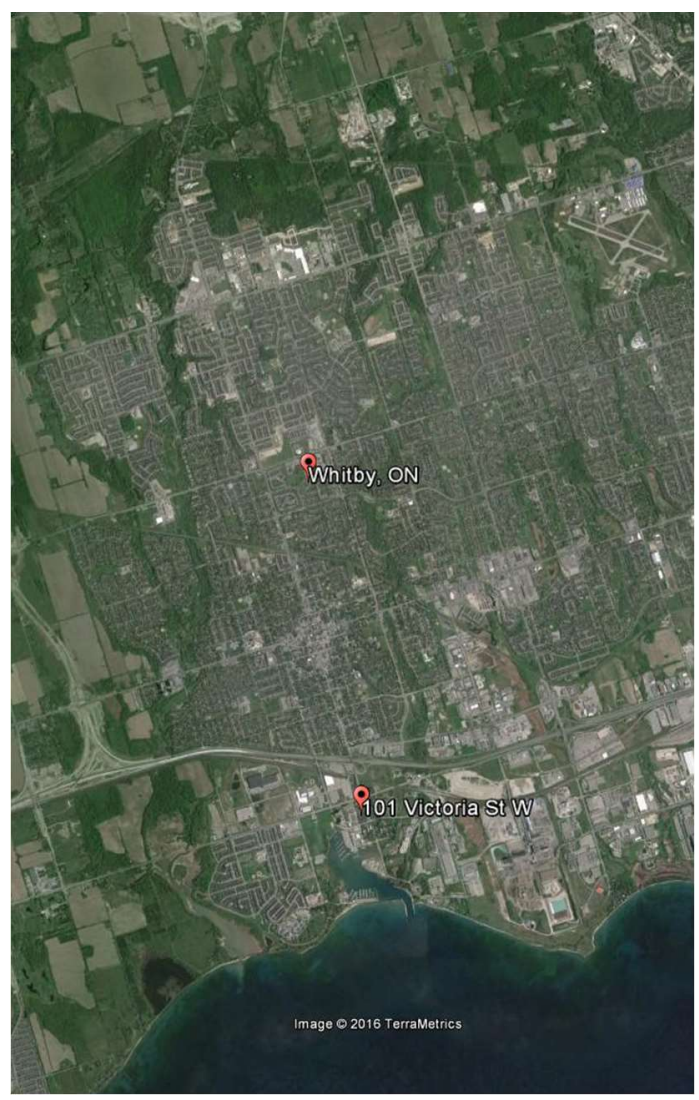

(Source: Google Earth, 2016)

\section{Figure 4: Surrounding Property Uses}

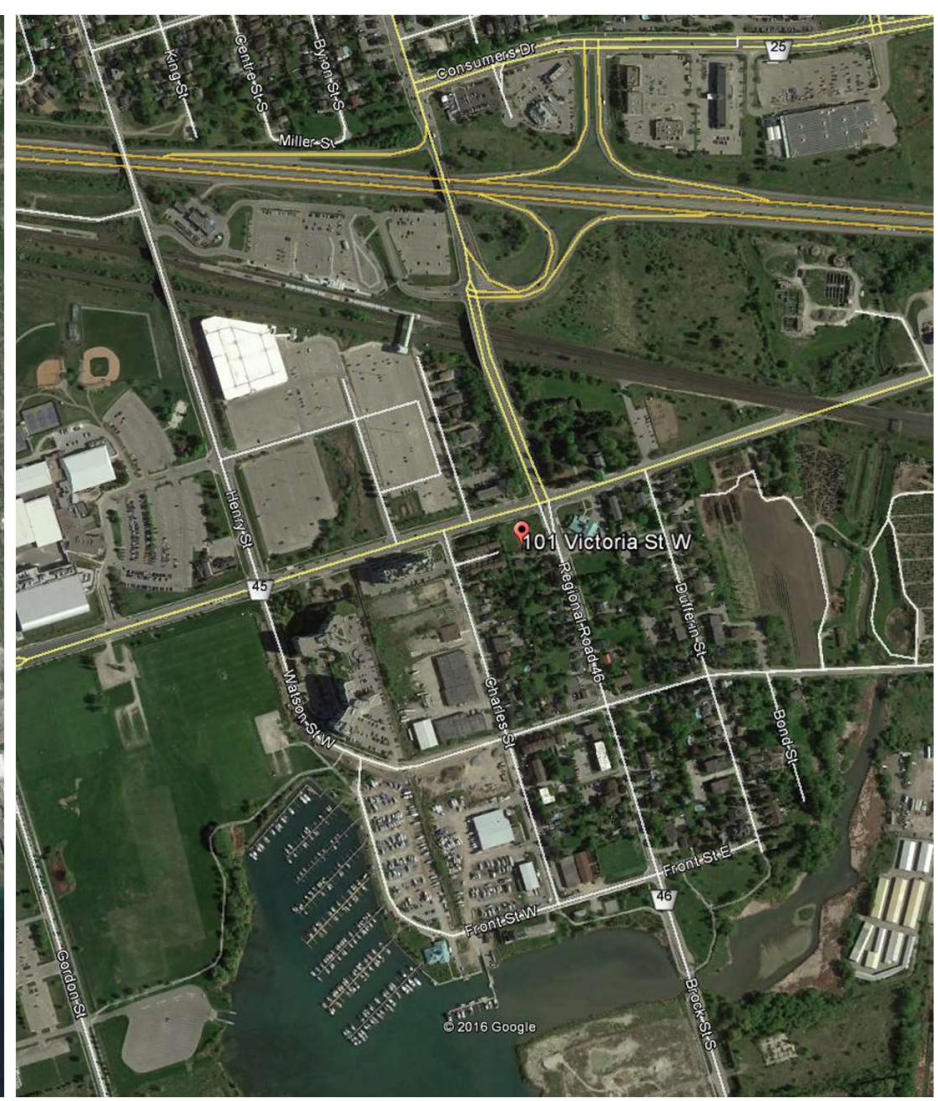

(Source: Google Earth, 2016)

This property is an excellent opportunity for the Town of Whitby to direct development in a way that conforms with its future OP goals of turning Brock St. South into a "main street" style development by encouraging street-facing retail, good urban design, and an improvement of the pedestrian realm. This development would also meet policy goals such as intensification through brownfield redevelopment, increasing density along transportation corridors, and increasing density near to higher-order public transit nodes (the nearby GO train station immediately to the northwest). A street-level picture of the property is shown below: 
Figure 5: Street-level Panorama of 101 Victoria Street West and Adjacent Properties

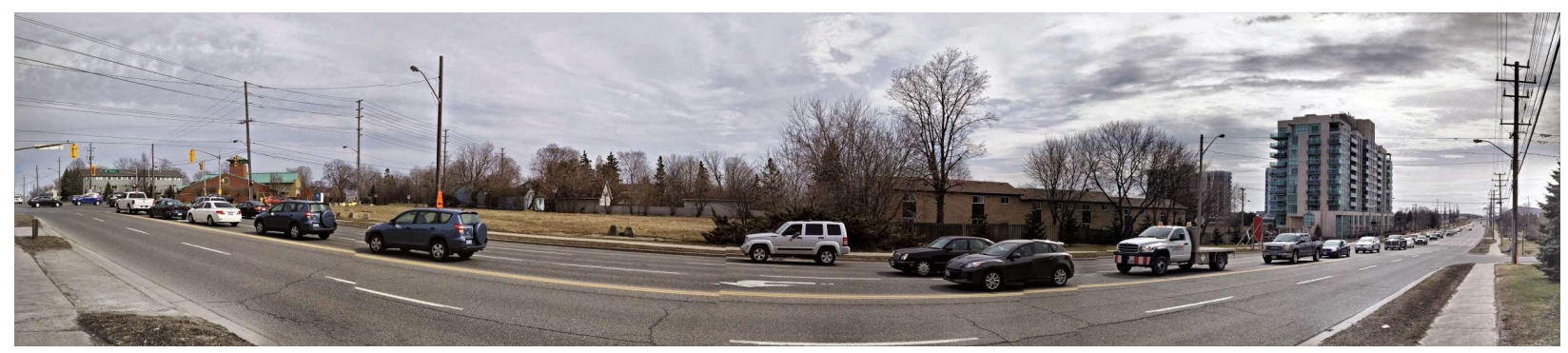

(Photo: Graham Wilson, April 2015)

To this end, it is recommended that a holding zone be placed on the Subject Property while the Town of Whitby's Official Plan is updated to include a CIP with the above incentives, which would apply to the Port Whitby Secondary Plan Area as well as other brownfield sites in Whitby. Following this, the Site Plan approval process should be used to ensure that the Subject Property is redeveloped in a way that supports the redesign of Brock St. S. and Victoria St. W. in this area. 


\section{Conclusion}

This research has shown that municipalities in Ontario use a variety of financial incentives for attracting brownfield development. Furthermore, it has shown that the need for and benefit from these incentives is strongly dependent on local market factors, specifically home sale prices. Other costs (construction, remediation, etc.) are generally consistent across markets; home sale prices are the strongest determinant of whether a project is financially feasible. This was made plain by comparing the selected municipality with the lowest sale price (Barrie) with the municipality with the highest sale price (Toronto). Based on available information, the scenario for Barrie was never feasible (ROE below $-200 \%$ ), with a loss of well beyond the environmental costs, while the scenario for Toronto was extremely profitable (ROE above $300 \%$ ) for all scenarios.

\section{Answering Research Questions}

1. Have stakeholders' impressions of the profitability (feasibility) of brownfield development changed in light of recent changes to the Environmental and planning regulatory framework?

Based on the responses received, the following trends were identified:

- Changes in the environmental regulatory framework have increased to complexity, cost, and time required for brownfield redevelopments, but have had little effect on liability concerns or public approval for redevelopment.

- Changes in planning policy have increased emphasis on brownfield redevelopment from greenfield development, but have also increased the complexity of redevelopment and reduced government and developer approval for brownfield redevelopment.

- Urban brownfield redevelopments were thought to cost more and take longer than suburban brownfield redevelopments, but nonetheless be much more profitable than the suburban equivalent.

As shown, the changes in the regulatory and planning policies were generally perceived to have a negative effect on the time required and cost of redevelopment, which would not increase the feasibility of suburban developments. This is consistent with the requirement for specific redevelopment incentives in suburban areas.

Finally, municipal governments were perceived by respondents to be the most supportive of brownfield redevelopment. This is not surprising, as most brownfield redevelopment incentives are generally provided by municipalities. 
2. Is brownfield development in Ontario suburbs financially feasible in comparison to Toronto, given lower market home prices?

Based on the results of the pro forma analysis, the feasibility of a redevelopment depends heavily on condo sale prices in that location, even before considering brownfield liabilities. The brownfield scenario used was profitable before incentives in both Hamilton and Waterloo, as well as Toronto (although by a much lower margin, with ROEs of $21 \%$ and $26 \%$ vs. $296 \%$ ). So although it was much less feasible in these areas, the scenario used would still have been profitable. In the three other locations considered (Barrie, Guelph, and Whitby), the scenario had an insufficient return in greenfield scenarios, and a negative return in brownfield scenario, due to lower market values.

3. Are existing financial incentives for brownfield redevelopment sufficient to close the feasibility gap and make suburban brownfield redevelopment financially feasible?

Based on the pro forma analysis, the existing financial incentives were able to increase the project's ROE by between $7 \%$ and $18 \%$; however, none of the existing financial incentives were sufficient to make the proposed development feasible where it was not before. This is likely the result of the configuration used in this analysis. The poor feasibility of this project in some areas, even without brownfield liabilities, is important because the Growth Plan (2006) directs municipalities in the Greater Golden Horseshoe (including all of the target municipalities, with some special provisions for Barrie) to accommodate additional population through intensification, which specifically includes the redevelopment of brownfields. Developments like this one are an important part of meeting the goals set out by the Growth Plan, so it is important that these policies recognize the market realities of attempting to encourage higher density built forms where they are not yet supported by stronger real estate markets.

Building materials were shown to improve the project in Whitby, with wooden construction increasing ROE by $17 \%$ before incentives (although still unfeasible at $-26 \%$ ROE before incentives), which allowed the financial incentives used in Windsor to make the project feasible at $22 \% \mathrm{ROE}$. This is because of the lower hard costs vs. concrete/steel hybrid construction. While additional density did not significantly increase ROE with municipalities (due to low market rates vs. consistent construction costs), different construction methods may help improve its benefit.

The recommended incentives for Whitby would make this project feasible, but only by allowing the developer to collect more in incentives than the total environmental costs. 


\section{Contribution to Research}

The results of this analysis was compared against a selection of the research papers reviewed, in order to identify whether these results supported or differed from their findings.

\section{De Sousa, 2000 - Stakeholder Interviews and Pro Forma analysis}

This research supported De Sousa's research, which showed that remediation costs, lengthy timelines, and regulatory complexity were seen as important barriers to redevelopment. Moreover, this research showed that perceptions of these aspects of redevelopments had gotten worse since the time of De Sousa's research.

De Sousa's pro forma analysis was a detailed comparison of residential vs. industrial developments, in a greenfield vs. brownfield perspective. This research had a different focus, but supported his findings that variations in unit sale price (\$ psf) has a strong effect on where a project is feasible or not, as well as his findings that governmental tax incentives have a strong effect on reducing the private costs of brownfield remediation. Finally, De Sousa's analysis of the effects of different non-financial incentives, specifically a shortened development period, is supported by the findings of this research as the additional delay of brownfield redevelopment resulted in high additional borrowing costs (from interest) which could outweigh the benefits of incentives (especially additional density, which results in additional hard costs and therefore higher carrying costs).

\section{De Sousa, 2006 - Surveys of Municipal stakeholders across Canada}

This research was not able to draw inferences about municipal opinions on brownfield redevelopment, due the low response rate from municipalities. However, this research does support De Sousa's conclusions about the perceptions of the roles of different levels of government; the federal government was viewed to be the least supportive stakeholder by many respondents, and received the lowest score of support overall. The provincial government was ranked only slightly higher.

In addition, this research confirms De Sousa's findings that urban brownfields often do not require incentives to be profitable, while suburban brownfields may remain unprofitable even after applying available incentives.

Hayek et al, 2010 - Interviews of brownfield redevelopment stakeholders in London, ON

This research generally supported Hayek's work, which identifies that brownfield redevelopments are challenged by financial and regulatory barriers. Hayek found that incentives were required to make developments feasible, but that they were sometimes not enough to make brownfield redevelopments attractive to developers. 


\section{Implications for Whitby, Ontario (and similar municipalities)}

The scenario for Whitby was not feasible as either a greenfield or brownfield development, and was only made feasible with modified construction materials and incentives greater than the total environmental costs. This has several important implications for redevelopment and intensification which are relevant to municipal planners:

- The density and configuration of development is constrained by market forces. A stated goal for a certain type of development is unlikely to be fulfilled by the private sector without the necessary market forces, or the appropriate incentives to make it profitable.

- If these development goals are considered vital to the municipality, achieving them would require public investment in private development until sale prices rise to allow the market to act alone. Incentives like Windsor's, which allow "double-dipping" on eligibly environmental costs, were the strongest incentive for enabling brownfield development. More significantly, they can enable a project to go forward with a built form or density which would not currently be feasible in that market, even on a greenfield site. This makes brownfield development more profitable than greenfield development, by allowing incentives above the total environmental remediation costs. While this represents additional costs to the municipality, this also represents an opportunity for Whitby to turn brownfield properties into "pilot" properties, which by virtue of their increased profitability can be the first to draw new development which implements OP goals.

\section{Further Research}

This research examined brownfield redevelopment from the perspective of individual sites and their financial feasibility. In order for municipalities to understand the large picture of the costs and benefits of brownfield redevelopment, more information is required.

Specifically, the economic benefits of brownfield redevelopment and increased density should be estimated; these may be based on the additional density that can be accommodated on a larger number of the existing brownfields within a municipality. This research would require estimates of the total brownfield area within a municipality, it's "highest and best use" under existing official plan policy, research on agglomeration benefits from increased density in these areas, and growth forecasts for the municipality. Were this benefit to be estimated, a municipality could decide how much money they were willing to invest in redevelopment through financial incentives, and where it would produce the greatest public benefit. 


\section{Reference List}

Altus Group. (2015). Construction Cost Guide 2015. Retrieved April 22, 2015 from http://www.altusgroup.com/media/199123/CostGuide 2015 web.pdf

BuzzBuzzHome. (2015). http://www.buzzbuzzhome.com

CBRE, Inc. (2015). Canadian Cap Rates \& Investment Insights: Q1 2015. http://www.cbre.ca/EN/services/capitalmarkets/Pages/investment-insights.aspx

City of Barrie. (2004). Downtown Next Wave Community Improvement Plan, 2004:

http://www.barrie.ca/Doing\%20Business/PlanningandDevelopment/Documents/Downtown Barri e-The Next Wave.pdf

City of Guelph. (2012). Brownfield Redevelopment Community Improvement Plan. http://guelph.ca/plans-and-strategies/brownfield-redevelopment/

City of Hamilton. (2013). Hamilton Economic Development Office: Municipal Programs. http://www.investinhamilton.ca/incentives/municipal-programs/

City of Hamilton. (2014). Erase Study Grant. Planning and Economic Development Department Economic Development Division. Retrieved Mar 17, 2015 from http://www.investinhamilton.ca/wp-content/uploads/2014/03/ERASE-STUDY-GRANTAPPLICATION.pdf

City of Oshawa. (2005). Brownfields Renaissance Community Improvement Plan. http://www.oshawa.ca/business-and-investment/resources/CIP Brownfields.pdf

City of Toronto. (2012). By-Law No. 1323-2012: Community Improvement Plan. https://www1.toronto.ca/static files/economic development and culture/docs/Citywide CIPbill1359-by-law 1323-2012.pdf

City of Toronto. (2015). Brownfield Remediation Tax Assistance. Retrieved Mar 17, 2015 fromhttp://www1.toronto.ca/wps/portal/contentonly?vgnextoid=725b4b5073cfa310VgnVCM1000 0071d60f89RCRD\&vgnextchannel=6e4032d0b6d1e310VgnVCM10000071d60f89RCRD

City of Waterloo. (2013). Brownfields Community Improvement Plan. http://www.waterloo.ca/en/government/brownfieldscommunityimprovementplan.asp

City of Windsor. (2015). Brownfield Redevelopment Community Improvement Plan. http://www.citywindsor.ca/residents/planning/Plans-and-Community-Information/Know-Your- 
Community/Community-Improvement/Pages/Brownfield-Redevelopment-Community$\underline{\text { Improvement-Plan.aspx। }}$

City of Windsor. (2015a). Report \#: S 18/2015: Brownfield Redevelopment and Economic Revitalization Community Improvement Plans (CIP) - 2015 Update and Responses to CQ8-2015 (City-wide). Forwarded by Greg Atkinson, MCIP, RPP, Senior Planner - Local Economic Development by email on November 2, 2015

Colliers International Canada. (2014). Multi-Family Report: Year End 2014. Retrieved Mar 14, 2015 fromhttp://www.collierscanada.com/en/Commercial-Property-Research.

Colliers International Canada. (2014a). Office Market Outlook: Q4 2014. Retrieved Mar 14, 2015 fromhttp://www.collierscanada.com/en/Commercial-Property-Research.

Crombie, David [Chair] et al. (2015). Planning for Health, Prosperity and Growth in the Greater Golden Horseshoe: 2015-2041. Recommendations of the Advisory Panel on the Coordinated Review of the Growth Plan for the Greater Golden Horseshoe, the Greenbelt Plan, the Oak Ridges Moraine Conservation Plan and the Niagara Escarpment Plan. Ontario: Queen's Printer for Ontario. ISBN 978-1-4606-6966-2 (Print). ISBN 978-1-4606-6957-0 (PDF).

Cushman \& Wakefield Ltd. (2012). Canadian Retail Market Update. http://www.realestateforums.com/realleasing/docs/RL2012 SessionA1.pdf

De Sousa, Christopher A. (2000). Brownfield Redevelopment versus Greenfield Development: A Private Sector Perspective on the Costs and Risks Associated with Brownfield Redevelopment in the Greater Toronto Area. Journal of Environmental Planning and Management, 43(6), pp 831-853

De Sousa, Christopher A. (2002). Brownfield redevelopment in Toronto: an examination of past trends and future prospects. Land Use Policy, Issue 19, pp 297-309.

De Sousa, Christopher A. (2006) Unearthing the benefits of brownfield to green space projects: An examination of project use and quality of life impacts, Local Environment: The International Journal of Justice and Sustainability, 11:5, 577-600

De Sousa, Christopher. (2006a). Urban brownfields redevelopment in Canada: the role of local government. The Canadian Geographer. 50, (3), 392-407.

De Sousa, Christopher. (2009). Assessing the Effect of Publicly Assisted Brownfield Redevelopment on Surrounding Property Values. Economic Development Quarterly, 23 (2), pp 95-110. 
EVALUATING SUBURBAN BROWNFIELD REDEVELOPMENT INCENTIVES

Durham Region. (2013). Durham Region Official Plan. Retrieved April 22, 2015 from http://www.durham.ca/planed.asp?nr=/departments/planed/planning/op documents/dr official_p lan 2008/OPmaps.htm\&setFooter=/includes/planningFooter.inc

Federation of Canadian Municipalities (FCM). (2014). Green Municipal Fund: Ontario Brownfield Roadmap, 2014.

https://www.fcm.ca/Documents/tools/GMF/Ontario Brownfields Roadmap Legislation and Fun ding Programs EN.pd $f$

Gibbons, J., \& Attoh-Okine, N. O. (2001). Use of belief function in brownfield infrastructure redevelopment decision making. Journal of Urban Planning and Development,127(3), 126-143. doi:10.1061/(ASCE)0733-9488(2001)127:3(126).

Greenberg, M. R. (2003). Reversing urban decay: Brownfield redevelopment and environmental health. Environmental Health Perspectives, 111(2), A74-a75. doi:10.1289/ehp.111-a74

Hayek, Michael; Godwin Arku; Jason Gilliland. (2010). Assessing London, Ontario's brownfield redevelopment effort to promote urban intensification, Local Environment: The International Journal of Justice and Sustainability, 15:4, 389-402

Howland, M. (2007). Employment effects of brownfield redevelopment: What do we know from the literature? Journal of Planning Literature, 22(2), 91-107. doi:10.1177/0885412207306616

IBI Group. (2008). Financial Incentive Programs for Downtown Renewal in Whitby. http://www.whitby.ca/en/resources/report incentivesreportprogram.pdf

iCompass Technologies Inc. (iCompass). (2014). Whitby Civicweb. Retrieved April 22, 2015 from https://whitby.civicweb.net/Documents/DocumentList.aspx

Koll-Schretzenmayr, M. (1999). From greenfield development to brownfield redevelopment: New challenges for planning process, planning strategies and planning law. DisP - the Planning Review, 35(139), 43. doi:10.1080/02513625.1999.10556724

MAH. (2015). Tax Increment-Based Financing. http://www.mah.gov.on.ca/Page1301.aspx

MAH. (2015a). Financing a Brownfield Project. http://www.mah.gov.on.ca/Page223.aspx

MAH. (2015b). Co-ordinated Land Use Planning Review. http://www.mah.gov.on.ca/Page10882.aspx

Metcalf, S. S., BenDor, T. K., \& Paich, M. (2011). The dynamics of brownfield redevelopment. Sustainability, 3(6), 914-936. doi:10.3390/su3060914 
Meyer, P. B., \& Lyons, T. S. (2000). Lessons from private sector brownfield redevelopers: Planning public support for urban regeneration. Journal of the American Planning Association, 66(1), 46. doi:10.1080/01944360008976083

Ministry of Municipal Affairs and Housing (MMAH). (2005). Greenbelt Plan. www.mah.gov.on.ca

Ministry of Municipal Affairs and Housing (MMAH). (2010). Municipal Financial Incentives for Brownfield Redevelopment: Trends among Ontario Municipalities. http://www.mah.gov.on.ca/AssetFactory.aspx?did=9590

Ministry of Municipal Affairs and Housing (MMAH). (2014). 2014 Provincial Policy Statement Under the Planning Act. www.mah.gov.on.ca

Ministry of Public Infrastructure Renewal (MPIR). (2006). Growth Plan for the Greater Golden Horseshoe. https://www.placestogrow.ca/content/ggh/GPGGH 2006 ENG.pdf

National Round Table on the Environment and the Economy (NRTEE). (1998). State of the debate on the environment and the economy: greening Canada's brownfield sites. Ottawa: Renouf Publishing Co. Ltd.

National Round Table on the Environment and the Economy (NRTEE). (2003). Cleaning up the Past, Building the Future: A National Brownfield Redevelopment Strategy for Canada. Ottawa: Renouf Publishing Co. Ltd.

Neuman, W. L. and Robson, K. (2012). Basics of Social Research, Second Canadian Edition. Toronto: Pearson Canada.

Niagara Falls. (2009). Environmental Study Grant Program: Brownfield Community Improvement Plan. Retrieved Mar 17, 2015 fromhttp://www.niagarafalls.ca/pdf/business/cip/brownfield/esgapplication-package.pdf

NRTEE \& CBN (The National Round Table on the Environment and the Economy and The Canadian Brownfields Network). (2005). Greening Canada's Brownfields: A National Framework for Encouraging Redevelopment of Qualifying Brownfields through Removal of Crown Liens and Tax Arrears.

Ontario Ministry of Municipal Affairs and Housing (MAH). (2012) Municipal Financial Incentives for Brownfield Redevelopment, Trends among Ontario Municipalities. Office of the Provincial Brownfields Coordinator. Retrieved from:

http://www.mah.gov.on.ca/AssetFactory.aspx?did=9590 
EVALUATING SUBURBAN BROWNFIELD REDEVELOPMENT INCENTIVES

Realnet Canada Inc. \& N. Barry Lyon Consultants Limited. (2011). The Lyon Report August 2011. Retrieved (Mar 17, 2015) from http://nblc.com/wp-content/uploads/2013/08/Hard-CopyAugust.pdf

Reese, Laura A. (2014). The Alchemy of Local Economic Development. Economic Development Quarterly 2014, Vol. 28(3) 206-219

Regional Municipality of Durham (Durham). (2015). Report No. 2015-J-35: The Regional Revitalization Program and other Regional Approaches to Supporting Revitalization Projects in Durham Region, File: D24-02.

https://zyimage.durham.ca/Exe/ZyNET.exe?ZyAction=ZyActionP\&Client=RoD\&Index=Regional \%20Commissioners $\% 20$ Reports\&Docs $=\& Q u e r y=\% 2 A 2015-\mathrm{j}-35$

Teranet Enterprises Inc. (TEI). (2014). Geowarehouse: Title Search and Land Titles. http://www.geowarehouse.ca/marketing/index.php

The Canadian Real Estate Association. (2015). Real Estate Listings in Canada. http://www.realtor.ca/

Town of Whitby. (2004, February). Downtown Whitby Community Improvement Plan. http://www.whitby.ca/en/discoverwhitby/resources/PL-DWHCD-OtherInformationDowntownWhitbyCIP.pdf

Town of Whitby. (2010). Official Plan. Retrieved April 22, 2015 from http://www.whitby.ca/en/residents/officialplan1994.asp

Town of Whitby. (2011). Recommendation Report PL 45-11: Application to Amend the Town of Whitby Official Plan and Zoning By-law No. 2585. http://www2.whitby.ca/asset/cs-report pl4511e20110613.pdf

Town of Whitby. (2012). Report No. PL 76-12: Staff Report - Downtown Whitby Development Steering Committee (DWDSC) - 2011 Strategic Action Plan Update: Town of Whitby Comments. http://www.whitby.ca/en/townhall/resources/PL-ReportPL7612-DWDSC-e201211051900.pdf

Town of Whitby. (2015, September). Port Whitby Community: Community Improvement Plan. http://svnap.com/wp-content/uploads/2015/09/150923-Final-Draft-CIP.pdf

Town of Whitby. (2015a). 2015 Capital Budget: Studies, Initiatives and Reserve Transfers: Downtown Improvement Projects [p. 484]. http://www.whitby.ca/en/resources/cs_2015capitalbudgetstudiesinitiativesandreservetransfers.pdf. 2015 Budget: http://www.whitby.ca/en/townhall/budget.asp 
EVALUATING SUBURBAN BROWNFIELD REDEVELOPMENT INCENTIVES

Town of Whitby. (n.d.). Explore Whitby - GIS Tools. Retrieved April 22, 2015 from http://www.whitby.ca/en/discoverwhitby/explorewhitbygistools.asp

Town of Whitby. (n.d.). Planning and Development. Retrieved April 22, 2015 from http://www.whitby.ca/en/townhall/planning.asp

Town of Whitby. (n.d.). Port Whitby Plan. Retrieved April 22, 2015 from http://www.whitby.ca/en/townhall/portwhitbyplan.asp

Town of Whitby. (n.d.). Port Whitby Sustainable Community Plan. Retrieved April 22, 2015 from http://www.whitby.ca/en/townhall/portwhitbysustainablecommunityplan.asp

Wang, Qian; Keith W. Hipel; D. Marc Kilgour. (2008). Conflict Analysis in Brownfield Redevelopment: The ERASE Program in Hamilton, Ontario. 2008 IEEE International Conference on Systems, Man and Cybernetics (SMC 2008)

Weber, Rachel; Laura Goddeeris. (2007). Lincoln Institute of Land Policy. Tax Increment Financing: Process and Planning Issues [working paper, code WP07RW1]. https://www.lincolninst.edu/subcenters/teaching-fiscal-dimensions-ofplanning/materials/goddeeris-weber-financing.pdf

Yu, Soonyoung; Andre J.A. Unger; Beth Parker; Taehee Kim. (2012). Allocating risk capital for a brownfields redevelopment project under hydrogeological and financial uncertainty. Journal of Environmental Management Volume 100, 15 June 2012, Pages 96-108 